\title{
Influence of Altitude on the Petrological Features of a Soil Climosequence in the Humid Tropical Zone of Cameroon
}

\author{
Dieudonné Bitom ${ }^{*}, 1$, Primus Azinwi Tamfuh ${ }^{1}$, Lionelle Mamdem², Philémon Zo’o Zame ${ }^{1}$, Olivier \\ Leumbe Leumbe $^{3}$, Lucian Banakeng ${ }^{1}$, Rosy Keugne ${ }^{1}$ and Paul-Désiré Ndjigui ${ }^{1}$ \\ ${ }^{I}$ Department of Earth Sciences, University of Yaoundé I, P.O. Box: 812 Yaoundé, Cameroon \\ ${ }^{2}$ Department of Earth Sciences, University of Ngaoundéré, P.O. Box: 454 Ngaoundéré, Cameroon \\ ${ }^{3}$ National Institute of Cartography, P.O. Box: 157 Yaoundé, Cameroon
}

\begin{abstract}
Although lateritic soils are well documented in the humid tropical zone, work on adiabatic effect, which imposes local climatic variations with increasing altitude, has received very little attention in this zone. The aim of this work was to study and specify a soil climosequence in the humid tropical zone of Cameroon and to show the influence of altitude on the geochemical functioning of tropical soils. The work was done in the field and completed by a battery of laboratory analyses. The results enabled the definition of a soil climosequence for the humid tropical zone in Cameroon. This climosequence is marked by soils whose evolution is conditioned by the geochemistry of iron, silicon and aluminium. In the plateau ecosystems (500-800 m altitude), iron is expressed either as hardened materials (e.g. ferruginous nodules or duricrust) or light patches on the soils, while silicon and aluminium are combined as kaolinite. In the high plateaus (800-2000 m altitude), soil evolution is dominated by aluminium geochemistry, where aluminium forms gibbsite (either indurated or loose) often associated with small amounts of goethite and hematite. Finally, in the mountainous massifs (> $2000 \mathrm{~m}$ altitude), soil evolution is controlled by silica geochemistry, where silica is combined with amorphous aluminium to form allophane. In this soil, the presence of a dark and thick humiferous andosolic horizon in the upper part of the profile is very remarkable. Overall, this soil climosequence reflects geochemical functioning processes which grade with altitude in the humid tropical zone of Cameroon, similar to that commonly observed under the temperate climate. This general scheme could be extrapolated to other humid tropical regions with similar climatic and relief conditions as those observed in Cameroon. However, this general tendency often includes site-specific modifications caused by human activity and local variations of environmental conditions.
\end{abstract}

Keywords: Allophane, amorphous minerals, adiabatic effect, gibbsite, iron oxides, kaolinite, silica.

\section{INTRODUCTION}

The intertropical zone covers about $35 \%$ of total land surface of the globe [1]. This zone shows successive convex and convexo-concave hills, which often transit progressively into pediments around the tropics [2,3]. These hills make up much of the tropical plateau landscapes $(500$ and $800 \mathrm{~m}$ altitude). The latter are surmounted primarily by high plateaus ( 800 to $1800-2000 \mathrm{~m}$ ) and secondly by mountainous massifs (>2000 m altitude) which impose considerable modifications to climate and vegetation distribution. These modifications have a direct bearing on the geochemical behaviour and nature of soils [2]. Hence, ferruginous duricrusts are omnipresent in tropical plateaus [4-8]. In the high plateaus, the ferruginous duricrusts are replaced by bauxitic duricrusts $[9,10]$. Finally in the tropical mountainous landscapes, andosols are predominant notably on volcanic rocks [11-15]. Associated with these three ecosystems are low plateaus and depressions $(<400 \mathrm{~m}$ altitude) where sedimentation processes condition the soil's

*Address correspondence to this author at the Laboratory of Soil Science, Faculty of Science, University of Yaoundé 1, B.P. 812, Yaoundé, Cameroon; Tel: (237) 993214 55; E-mail: bitomoyono@yahoo.fr geochemical functioning [1]. Much work has already been published on lateritic soils in the humid tropical zone. Some work was dedicated to their nature, inventory and spatial distribution $[1,5,8,10,11,13,14,16]$, their geochemicaland mineralogical composition $[1,3,5,7,9,10]$, their morphology and micromorphology $[1,8,16]$ and the influence of environmental factors on the nature of their constituents $[3,5,9$, 17]. Although most of those works were based on isolated weathering profiles and topo-sequences, the works of Hiéronymus [9] and Duchaufour [17] signalled the presence of a veritable climosequence in relation to variation of altitude and climate in tropical landscapes similar to those commonly documented in temperate zones. However, work in which all these aspects have been treated together in detail under varying climatic conditions based on increasing altitude has received very little attention in the humid tropical zone. The lack of attention is due to a number of constraints including the need for multiplicity of the study sites, the time required for sampling and analysis, the high number of samples and a wide battery of laboratory analyses that prevent many investigators from conducting such studies in most developing countries. The aim of the present work is to study and specify the characteristics of a soil climosequence in the intertropical zone on a morphological, mineralogical and geochemical point of view, 


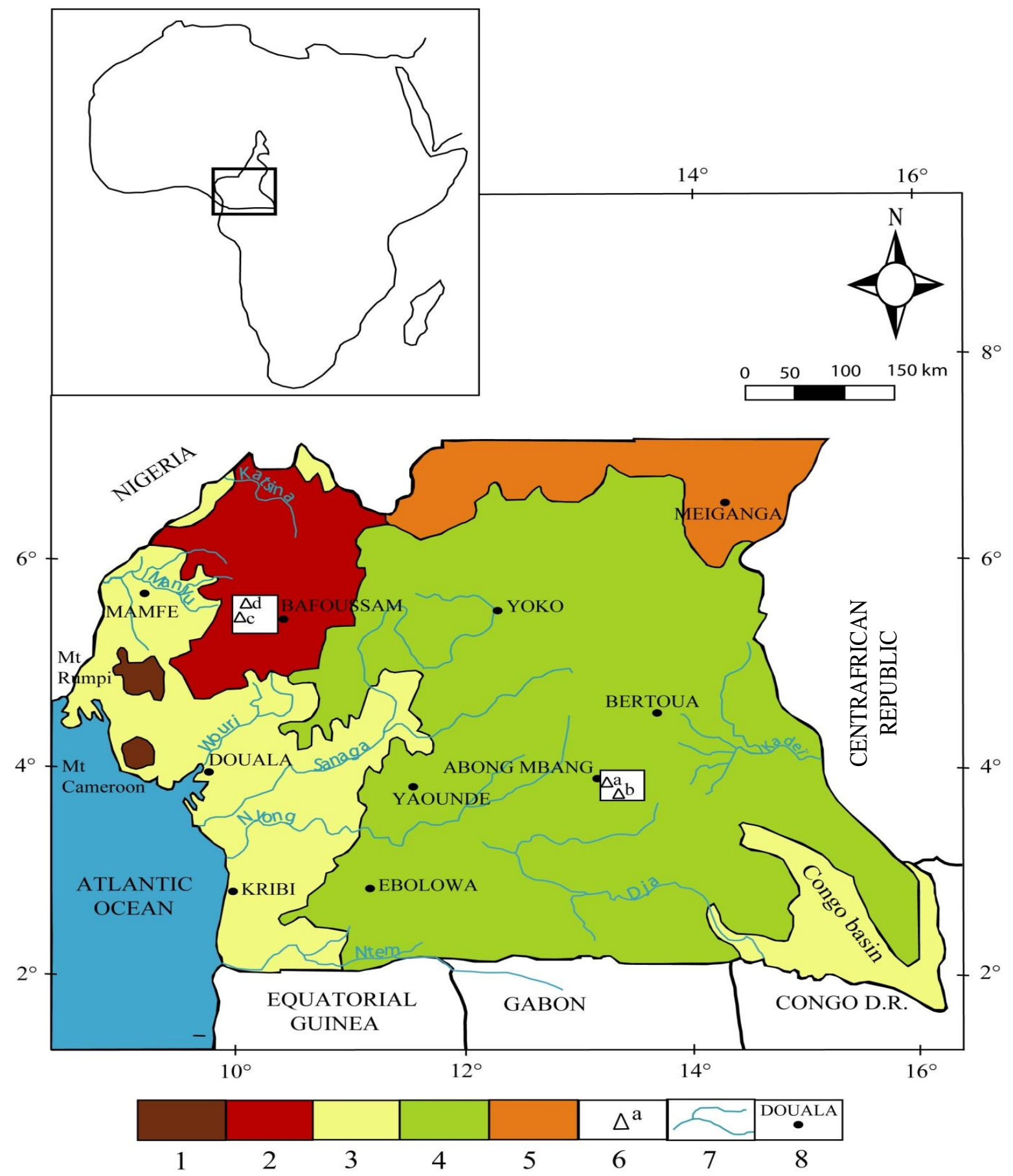

Fig. (1). Main ecological zones of South Cameroon and location of study sites. 1: Mountainous massifs (> 2000 m altitude); 2: Western Highlands of Cameroon (800-900 to beyond $4000 \mathrm{~m}$ altitude); 3: Low plateaus, coastal plain and depressions (0 - $400 \mathrm{~m}$ altitude); 4 : South Cameroon Plateau (500-800 m altitude); 5: Adamawa Plateau (900 - 1300 m altitude); 6: Study sites: a) "Mayos site"; b) "Mbalam" site; c) "Meloung site"; d) "Meleta site"; 7: Rivers; 8: Localities.

and to check the influence of altitude on the nature and geochemistry of humid tropical soils.

\section{MATERIAL AND METHODS}

\subsection{Study Site Description}

The study was located in the South Cameroon below latitude $8^{\circ} \mathrm{N}$, and four sites were selected including "Mayos", "Mbalam", "Meloung" and "Meleta" (Fig. 1).
The "Mayos site", with an altitude of $730 \mathrm{~m}$, is a tropical plateau located in the South Cameroon Plateau [2]. Its geographic coordinates are longitude $13^{\circ} 20^{\prime} 05^{\prime \prime}$ to $37^{\prime \prime}$ East and latitude $3^{\circ} 48^{\prime} 02^{\prime \prime}$ to $3^{\circ} 49^{\prime} 07^{\prime \prime}$ North (Fig. 1). The climate is the "Guinean-type", with two dry seasons alternating with two humid ones of unequal intensities [18]. The mean annual temperature is $23.4^{\circ} \mathrm{C}$ and the annual precipitation is $1677 \mathrm{~mm}$. The average relative humidity is $80 \%$. The vegetation is a dense semi-deciduous forest, 
locally replaced by raffia bushes in the swampy valleys [19]. The site is an interfluve with flat convex top and gentle slopes $(\leq 5 \%)$, bordered by wide and swampy $25 \mathrm{~m}$ deep Ushaped valleys. The bedrock consists of mica-schist with muscovite, biotite, quartz, feldspar and garnet. The average chemical composition of the mica-schist shows silica (57.70 $\left.\% \mathrm{SiO}_{2}\right)$, alumina $\left(17.03 \% \mathrm{Al}_{2} \mathrm{O}_{3}\right)$, accessory iron $(6.62 \%$ $\mathrm{Fe}_{2} \mathrm{O}_{3}$ ) and bases $\left(4.12 \% \mathrm{~K}_{2} \mathrm{O}, 3.20 \% \mathrm{Na}_{2} \mathrm{O}, 2.13 \% \mathrm{MgO}\right.$ and $2.01 \% \mathrm{CaO}$ ) (Table $\mathbf{1}$ ).

The "Mbalam site", $8 \mathrm{~km}$ from "Mayos", is also located in the South Cameroon Plateau (Fig. 1). The climate and vegetation are similar to those of "Mayos". With an altitude of $840 \mathrm{~m}$, this plateau belongs to the high plateau tropical landscape ecosystem. It is an asymmetric interfluve with a convex top and steep slopes (6 to $10 \%$ ), limited by narrow $\mathrm{V}$-shaped valleys. The bedrock is a garnet mica-schist, constituted by garnet, muscovite, biotite, quartz, feldspars and calcite. The mean chemical composition is close to that of Mayos, but for higher $\mathrm{Si}\left(64.01 \% \mathrm{SiO}_{2}\right)$ and lower $\mathrm{Al}$ $\left(14.40 \% \mathrm{Al}_{2} \mathrm{O}_{3}\right.$ ) contents (Table 2).

The "Meloung" and "Meleta" sites are located in the Western Highlands of Cameroon (Fig. 1), in the Bambouto

Table 1. Chemical Composition of the Plateau Soils and Rocks ("Mayos Site" in the South Cameroon Plateau)

\begin{tabular}{|c|c|c|c|c|c|c|c|c|c|c|c|c|c|c|}
\hline \multicolumn{2}{|c|}{ Horizons } & $\mathrm{SiO}_{2}$ & $\mathbf{A l}_{2} \mathbf{O}_{3}$ & $\mathrm{Fe}_{2} \mathrm{O}_{3}$ & $\mathrm{TiO}_{2}$ & $\mathbf{K}_{2} \mathrm{O}$ & $\mathrm{Na}_{2} \mathrm{O}$ & MgO & $\mathrm{CaO}$ & MnO & $\mathbf{P}_{2} \mathbf{O}_{5}$ & LOI & Total & $\frac{S i}{A l}$ \\
\hline $\begin{array}{l}\text { Red clayey set } \\
(2 \mathrm{~m})\end{array}$ & Bulk fraction & 57.55 & 15.08 & 6.01 & 1.02 & 4.45 & 2.24 & 1.81 & 2.30 & - & 0.33 & 13.23 & 99.20 & 3.42 \\
\hline \multirow{4}{*}{$\begin{array}{l}\text { Spotted and } \\
\text { compact } \\
\text { ferruginous } \\
\text { nodular } \\
\text { horizon ( } 4.50 \\
\mathrm{~m})\end{array}$} & Nodules & 19.81 & 17.38 & $4 . .23$ & 0.51 & 0.83 & 0.08 & 0.15 & 0.02 & $<\mathrm{dl}$ & 0.20 & 10.16 & 98.36 & 1.02 \\
\hline & Red patches & \multirow{3}{*}{\multicolumn{13}{|c|}{ Not analysed }} \\
\hline & Yellow patches & & & & & & & & & & & & & \\
\hline & Matrix & & & & & & & & & & & & & \\
\hline \multirow{3}{*}{$\begin{array}{l}\text { Blocky iron } \\
\text { duricrust } \\
\text { horizon }(2 \mathrm{~m})\end{array}$} & $\begin{array}{l}\text { Massive iron } \\
\text { duricrust }\end{array}$ & 32.00 & 16.15 & 40.30 & 0.44 & 0.51 & $<\mathrm{dl}$ & 0.12 & $<\mathrm{dl}$ & $<\mathrm{dl}$ & 0.11 & 9.65 & 99.28 & 1.77 \\
\hline & $\begin{array}{l}\text { Alveolar iron } \\
\text { duricrust }\end{array}$ & 28.33 & 19.38 & 41.28 & 0.68 & $<\mathrm{dl}$ & $<\mathrm{dl}$ & 0.25 & $<\mathrm{dl}$ & $<\mathrm{dl}$ & 0.07 & 9.92 & 99.92 & 1.31 \\
\hline & $\begin{array}{l}\text { Isalteritic iron } \\
\text { duricrust }\end{array}$ & 8.64 & 7.65 & 68.26 & 0.16 & $<\mathrm{dl}$ & $<\mathrm{dl}$ & $<\mathrm{dl}$ & $<\mathrm{dl}$ & 0.29 & 0.71 & 13.75 & 99.46 & 1.01 \\
\hline \multirow{2}{*}{$\begin{array}{l}\text { Ferruginous } \\
\text { pebbly horizon } \\
(5 \mathrm{~m})\end{array}$} & Pebbles & 31.38 & 21.97 & 30.27 & 1.00 & 3.24 & 0.19 & 0.56 & $<\mathrm{dl}$ & $<\mathrm{dl}$ & 0.17 & 9.64 & 98.44 & 1.28 \\
\hline & Matrix & 49.09 & 23.87 & 12.33 & 1.59 & 1.10 & $<\mathrm{dl}$ & 0.26 & $<\mathrm{dl}$ & 0.02 & 0.09 & 10.34 & 98.69 & 1.86 \\
\hline \multirow{3}{*}{$\begin{array}{r}\text { Spotted } \\
\text { horizon } \\
(4.5 \mathrm{~m})\end{array}$} & $\begin{array}{l}\text { Hardened red } \\
\text { domains }\end{array}$ & 12.81 & 13.45 & 56.33 & 0.94 & $<\mathrm{dl}$ & $<\mathrm{dl}$ & 0.02 & $<\mathrm{dl}$ & $<\mathrm{dl}$ & 0.36 & 14.81 & 98.73 & 0.90 \\
\hline & Red patches & \multirow{2}{*}{\multicolumn{13}{|c|}{ Not analysed }} \\
\hline & Yellow patches & & & & & & & & & & & & & \\
\hline \multirow{4}{*}{$\begin{array}{l}\text { Mottled } \\
\text { horizon } \\
(4.65 \mathrm{~m})\end{array}$} & $\begin{array}{l}\text { Whitish gray } \\
\text { domains }\end{array}$ & 47.50 & 23.72 & 17.38 & 0.62 & 0.50 & $<\mathrm{dl}$ & 0.18 & $<\mathrm{dl}$ & 0.08 & 0.18 & 10.79 & 100.95 & 1.79 \\
\hline & Red domains & 45.30 & 23.83 & 19.77 & 0.15 & 0.78 & $<\mathrm{dl}$ & 0.24 & 0.04 & 0.02 & 0.17 & 10.41 & 100.71 & 1.79 \\
\hline & $\begin{array}{l}\text { Yellowish } \\
\text { brown isalteritic } \\
\text { domains }\end{array}$ & 34.10 & 18.25 & 31.64 & 0.51 & 0.20 & $<\mathrm{dl}$ & 0.08 & $<\mathrm{dl}$ & 0.04 & 0.72 & 13.19 & 98.73 & 1.68 \\
\hline & $\begin{array}{l}\text { Reddish brown } \\
\text { isalteritic } \\
\text { domains }\end{array}$ & \multirow{2}{*}{\multicolumn{13}{|c|}{ Not analysed }} \\
\hline \multirow{2}{*}{$\begin{array}{l}\text { Alloteritic } \\
\text { horizon } \\
(8 \mathrm{~m})\end{array}$} & Nodules & & & & & & & & & & & & & \\
\hline & Matrix & 56.03 & 24.42 & 8.07 & 1.54 & 1.88 & 0.11 & 0.41 & $<\mathrm{dl}$ & 0.03 & 0.12 & 9.30 & 101.91 & 2.05 \\
\hline $\begin{array}{l}\text { Isalteritic } \\
\text { horizon }(9.6 \mathrm{~m})\end{array}$ & Bulk fraction & 55.80 & 28.30 & 5.64 & 1.35 & 3.74 & 0.43 & 0.68 & 0.02 & $<\mathrm{dl}$ & 0.07 & 1.66 & 97.70 & 1.79 \\
\hline \multicolumn{2}{|c|}{ Mica -schist } & 57.67 & 17.03 & 6.62 & 0.89 & 4.12 & 3.20 & 2.13 & 2.01 & - & 0.27 & 11.61 & 10.94 & - \\
\hline
\end{tabular}


Table 2. Chemical Composition of the High Plateau Soils and Rocks ("Mbalam Site" in the South Cameroon Plateau)

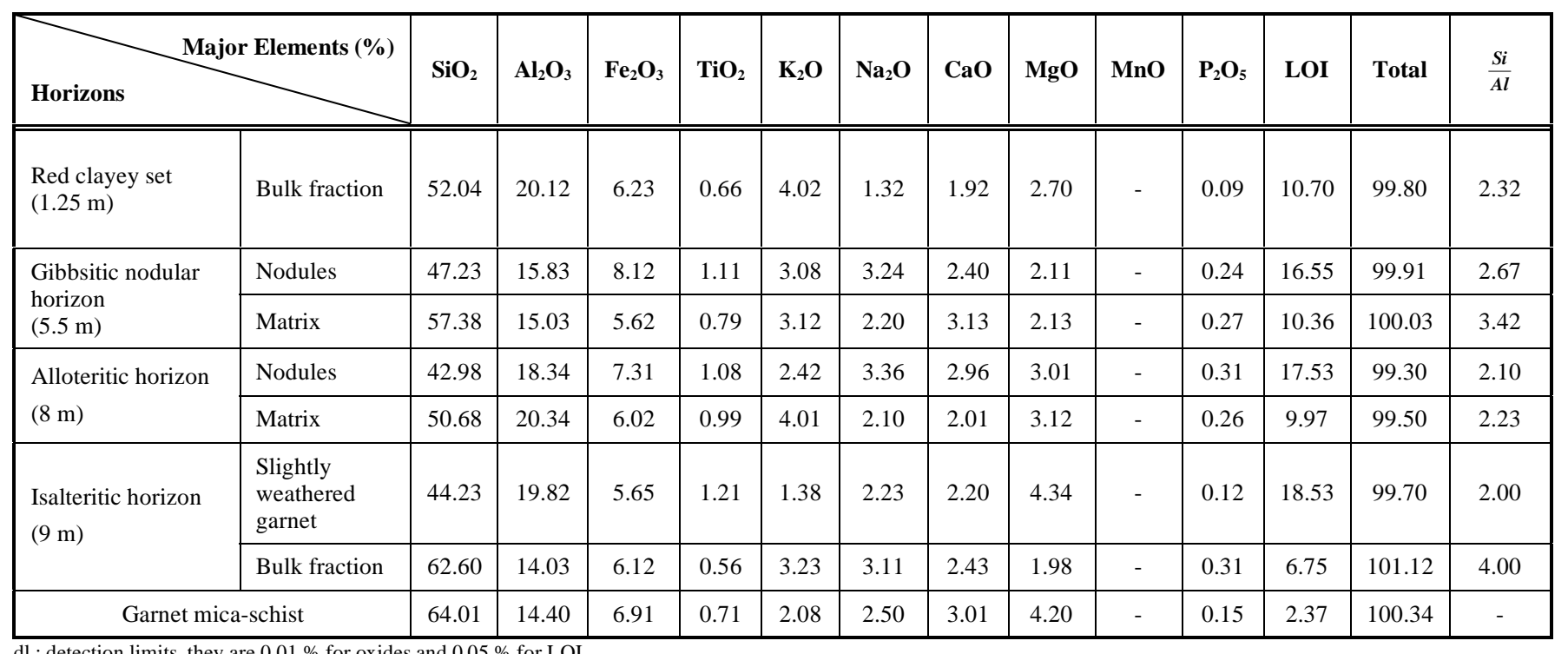

dl.: detection limits, they are $0.01 \%$ for oxides and $0.05 \%$ for LOI.

Mountains (2740 $\mathrm{m}$ altitude). The Western Highlands rise above the South Cameroon Plateau in the North West (Fig. 1).

The "Meloung site", with an altitude of $1844 \mathrm{~m}$, constitutes a portion of the high plateau. It is located between latitude $5^{\circ} 33^{\prime} 13^{\prime \prime}$ and $5^{\circ} 34^{\prime} 07^{\prime \prime}$ North, and longitude $10^{\circ} 04^{\prime} 20^{\prime \prime}$ and $10^{\circ} 05^{\prime} 16^{\prime \prime}$ East. The climate is cool and humid, while the mean annual temperature and precipitation are $17.39{ }^{\circ} \mathrm{C}$ and $1656 \mathrm{~mm}$, respectively. The relative humidity is very high $(95 \%)$. The site is an asymmetric interfluve with a convex top and convexoconcave gentle to steep slopes. The natural vegetation is strongly influenced by humans and has been replaced with crops like coffee, tea, potatoes, cabbage and carrots. The bedrock is sanidine trachyte composed of sanidine, pyroxene and opaque minerals. The average chemical composition shows that it is poor in aluminium $\left(16.50 \% \mathrm{Al}_{2} \mathrm{O}_{3}\right)$, but rich in silica $\left(62.50 \% \mathrm{SiO}_{2}\right)$ and alkaline elements $\left(6.29 \% \mathrm{~K}_{2} \mathrm{O}\right.$, $6.25 \% \mathrm{Na}_{2} \mathrm{O}$ ) (Table 3).
The "Meleta site" (2740 $\mathrm{m}$ altitude) belongs to the tropical mountainous massif ecosystem. The geographic coordinates are longitude $10^{\circ} 04^{\prime} 16^{\prime \prime}$ to $10^{\circ} 05^{\prime} 49^{\prime \prime}$ East, and latitude $5^{\circ} 36^{\prime} 43^{\prime \prime}$ to $5^{\circ} 38^{\prime} 31^{\prime \prime}$ North (Fig. 1). The climate is cool (mean annual temperature of 10 to $12^{\circ} \mathrm{C}$ ), humid ( $2507 \mathrm{~mm} /$ year) with thick and frequent mist and frost. The relief is uneven, characterized by steep slopes. The natural vegetation is a lawn grass Sporobolus with some trees along the river valleys. This vegetation has also been replaced with crops like cabbage, carrots and potatoes. The bedrock is similar to that at "Meloung", although with lower Si (58.00 $\left.\% \mathrm{SiO}_{2}\right)$ and higher $\mathrm{Al}\left(18.40 \% \mathrm{Al}_{2} \mathrm{O}_{3}\right)$ contents (Table 4).

\subsection{Methods}

Work was done both in the field and in the laboratory. In the field, landscape analysis of the different studied sites was first done. The main environmental parameters analyzed include relief, local climate, parent rock and vegetation. Landscape analysis was followed by a pedological assessment by means of a manual auger and pits, as well as

Table 3. Chemical Composition of the High Plateau Soils and Rocks ("Meloung Site" in the Cameroon Western Highlands)

\begin{tabular}{|l|l|l|l|l|l|l|l|l|l|l|l|l|l|l|}
\hline Horizons & Major Elements (\%) & $\mathbf{S i O}_{2}$ & $\mathbf{A l}_{2} \mathbf{O}_{3}$ & $\mathbf{F e}_{2} \mathbf{O}_{3}$ & $\mathbf{T i O}_{2}$ & $\mathbf{K}_{2} \mathbf{O}$ & $\mathbf{N a} \mathbf{O}$ & $\mathbf{C a O}$ & $\mathbf{M g O}$ & $\mathbf{M n O}$ & $\mathbf{P}_{2} \mathbf{O}_{5}$ & $\mathbf{L O I}$ & $\mathbf{T o t a l}$ & $\frac{S i}{A l}$ \\
\hline \hline $\begin{array}{l}\text { Humiferous horizon with Andosolic } \\
\text { properties (0.2 m) }\end{array}$ & Bulk fraction & 22.00 & 32.00 & 13.20 & 2.03 & 0.20 & 0.00 & 0.73 & 0.33 & 0,09 & 0.29 & 28.60 & 99.49 & 0.62 \\
\hline Red clayey set (0.5 m) & Bulk fraction & 11.40 & 40.90 & 19.30 & 1.84 & 0.06 & 0.00 & 0.02 & 0.07 & 0,18 & 0.12 & 25.70 & 99.59 & 0.25 \\
\hline Gibbsitic glaebular horizon (0.60 m) & Gibbsitic glaebular & 7.53 & 46.80 & 16.20 & 1.25 & 0.01 & 0.00 & 0.01 & 0.06 & 0,13 & 0.18 & 27.60 & 99.80 & 0.14 \\
\hline $\begin{array}{l}\text { Yellowish red alloteritic horizon (1.30 } \\
\text { m) }\end{array}$ & Bulk fraction & 16.70 & 39.00 & 17.40 & 1.93 & 0.07 & 0.00 & 0.03 & 0.09 & 0,11 & 0.07 & 24.20 & 99.60 & 0.39 \\
\hline Mottled isalteritic horizon (2.5m) & Red domains & 24.90 & 28.10 & 23.20 & 1.01 & 0.08 & 0.00 & 0.03 & 0.00 & 0,52 & 0.06 & 21.70 & 99.60 & 0.78 \\
\hline Whitish gray isalteritic horizon (4 m) & Bulk fraction & 47.80 & 25.00 & 8.40 & 0.87 & 2.71 & 2.80 & 0.27 & 0.18 & 0,21 & 0.13 & 11.20 & 99.60 & 1.71 \\
\hline Alkaline trachyte & & 62.50 & 16.50 & 5.62 & 0.73 & 6.30 & 6.25 & 0.54 & 0.30 & 0,27 & 0.09 & 0.49 & 99.60 & - \\
\hline
\end{tabular}

dl.: detection limits, they are $0.01 \%$ for oxides and $0.05 \%$ for LOI 
Table 4. Chemical Composition of Mountainous Massif Soils and Rocks ("Meleta Site" in the Cameroon Western Highlands)

\begin{tabular}{|c|c|c|c|c|c|c|c|c|c|c|c|c|c|c|}
\hline \multicolumn{2}{|l|}{ Horizons } & $\mathrm{SiO}_{2}$ & $\mathbf{A l}_{2} \mathbf{O}_{3}$ & $\mathrm{Fe}_{2} \mathrm{O}_{3}$ & $\mathrm{TiO}_{2}$ & $\mathbf{K}_{2} \mathrm{O}$ & $\mathrm{Na}_{2} \mathrm{O}$ & $\mathrm{CaO}$ & MgO & MnO & $\mathbf{P}_{2} \mathbf{O}_{5}$ & LOI & Total & $\frac{S i}{A l}$ \\
\hline $\begin{array}{l}\text { Humiferous } \\
\text { horizon with } \\
\text { Andosolic } \\
\text { properties } \\
(0.2 \mathrm{~m})\end{array}$ & $\begin{array}{l}\text { Bulk } \\
\text { fraction }\end{array}$ & 21.50 & 20.30 & 7.05 & 0.97 & 0.48 & $0, .5$ & 0.23 & 0.30 & 0.05 & 0.35 & 48.10 & 99.48 & 0.95 \\
\hline $\begin{array}{l}\text { Yellowish red } \\
\text { clay set }(0.7 \mathrm{~m})\end{array}$ & $\begin{array}{l}\text { Bulk } \\
\text { fraction }\end{array}$ & 23.80 & 34.00 & 8.75 & 1.08 & 0.60 & 0.20 & 0.08 & 0.29 & 0.30 & 0.32 & 30.20 & 99.62 & 0.63 \\
\hline \multirow{2}{*}{ Isalteritic horizon } & $\begin{array}{l}\text { Yellowish } \\
\text { brown } \\
\text { domains } \\
(1.45 \mathrm{~m})\end{array}$ & 23.50 & 39.10 & 8.94 & 0.73 & 0.12 & 0.00 & 0.00 & 0.13 & 0.14 & 0.29 & 28.00 & 100.95 & 0.54 \\
\hline & $\begin{array}{l}\text { Whitish } \\
\text { grey } \\
\text { domains } \\
(2 \mathrm{~m})\end{array}$ & 22.70 & 41.10 & 6.63 & 0.44 & 0.08 & 0.00 & 0.01 & 0.09 & 0.34 & 0.25 & 26.20 & 97.84 & 0.49 \\
\hline \multicolumn{2}{|l|}{ Alkaline trachyte } & 58.00 & 18.40 & 5.63 & 0.44 & 5.23 & 6.56 & 2.10 & 0.41 & 0.30 & 0.14 & 2.01 & 99.22 & - \\
\hline
\end{tabular}

dl.: detection limits, they are $0.01 \%$ for oxides and $0.05 \%$ for LOI.

description of the weathering mantles. Samples were collected for laboratory analyses and the colour was determined using a Munsell Soil Colour Chart [20].

In the laboratory, petrographic, mineralogical and geochemical analyses were performed. The petrographic analyses were done in the laboratory of the "Institut de Recherche pour le Développement" of Bondy (France) and in the Institute of Geological and Mining Research of Yaoundé (Cameroon). They involved the cutting of thin sections of rocks and weathered materials. Soil samples were first impregnated with resin and hardened in air before they were cut for microscopic observation [21]. The terminology adopted for thin section description is that of Brewer [22]. The mineralogical analyses were carried out in the "Institut Polytechnique de Lausanne" in Switzerland. They involved the X-ray diffraction of whole sample powder and separated fractions of horizons using a diffractometer with a copper anode and a xenon detector (wavelength, $\lambda=1.54 \times 10^{-10} \mathrm{~m}$ and energy $E=40 \mathrm{Kv}$ ). The mineral species were identified using standard tables [23]. The semi-quantitative analysis of minerals was completed by measuring the surface areas of the principal peaks and cross-checked by the clay X-ray computer software containing a database of reference minerals [24]. In the case of some samples from the "Meleta site" characterized by poorly defined reflections typical of amorphous or paracrystalline minerals, complementary analyses were performed by infrared spectroscopy [25] in the "Laboratoire de Minéralogie-Cristallographie" of Paris Jussieu (France). The chemical analyses of whole sample powders and separated fractions of horizons were done in the "Laboratoire de Géochimie Appliquée" of the "Université Technique de Berlin" (Germany) and the "Institut Polytechnique de Lausanne" (Switzerland). They were performed on disoriented sample powder using inductively coupled plasma-atomic emission spectrometry (ICP-AES) after fusion in $\mathrm{LiBO}_{2}$ and dissolution in nitric acid [26].

\section{RESULTS}

3.1. Morphological, Mineralogical and Geochemical Study of the Soils

\subsubsection{Macroscopic and Microscopic Characteristics}

\subsubsection{Morphological Characteristics of Plateau Soils at "Mayos"}

Eight principal soil horizons were identified in the studied soils, which from bottom to top, include: a yellowish grey isalteritic horizon, a red alloteritic horizon, a mottled horizon, a spotted horizon, a hardened ferruginous horizon, an iron blocky duricrust horizon, a ferruginous nodular horizon, a loose clayey set of horizons (Fig. $\mathbf{2 A}$ ).

The isalteritic horizon, several meters thick, is loose and loamy, with a perfectly conserved original schistose structure of the underlying parent rock. Under the microscope, it shows a groundmass (GM) composed of yellowish grey, weakly abundant (10\% of GM) plasma (non-skeletal component of groundmass), with a silasepic structure, and very abundant skeletal grains composed of muscovite (70\% of GM) and quartz (5\% of GM). The voids, principally dissolution and mineral piling type, make up $15 \%$ of GM. Most of the muscovite minerals are in the process of weathering, by progressive kaolinite pseudomorphosis.

The alloteritic horizon is $1.5-3 \mathrm{~m}$ thick (Fig. 2A). It shows lightly hardened ferruginous nodules and centimetre scale isalteritic relics completely buried in a very abundant (> $60 \%$ of the horizon), red (10R4/4) to dark red (10YR3/4), loose clayey matrix. The nodules are brown to reddish brown. Microscopically, the plasma is isotic and rich in muscovite more or less weathered to kaolinite.

The mottled and spotted horizons are located at the extreme foot of the slope; these horizons laterally replace the weathering facies, with the spotted horizon overlying the 


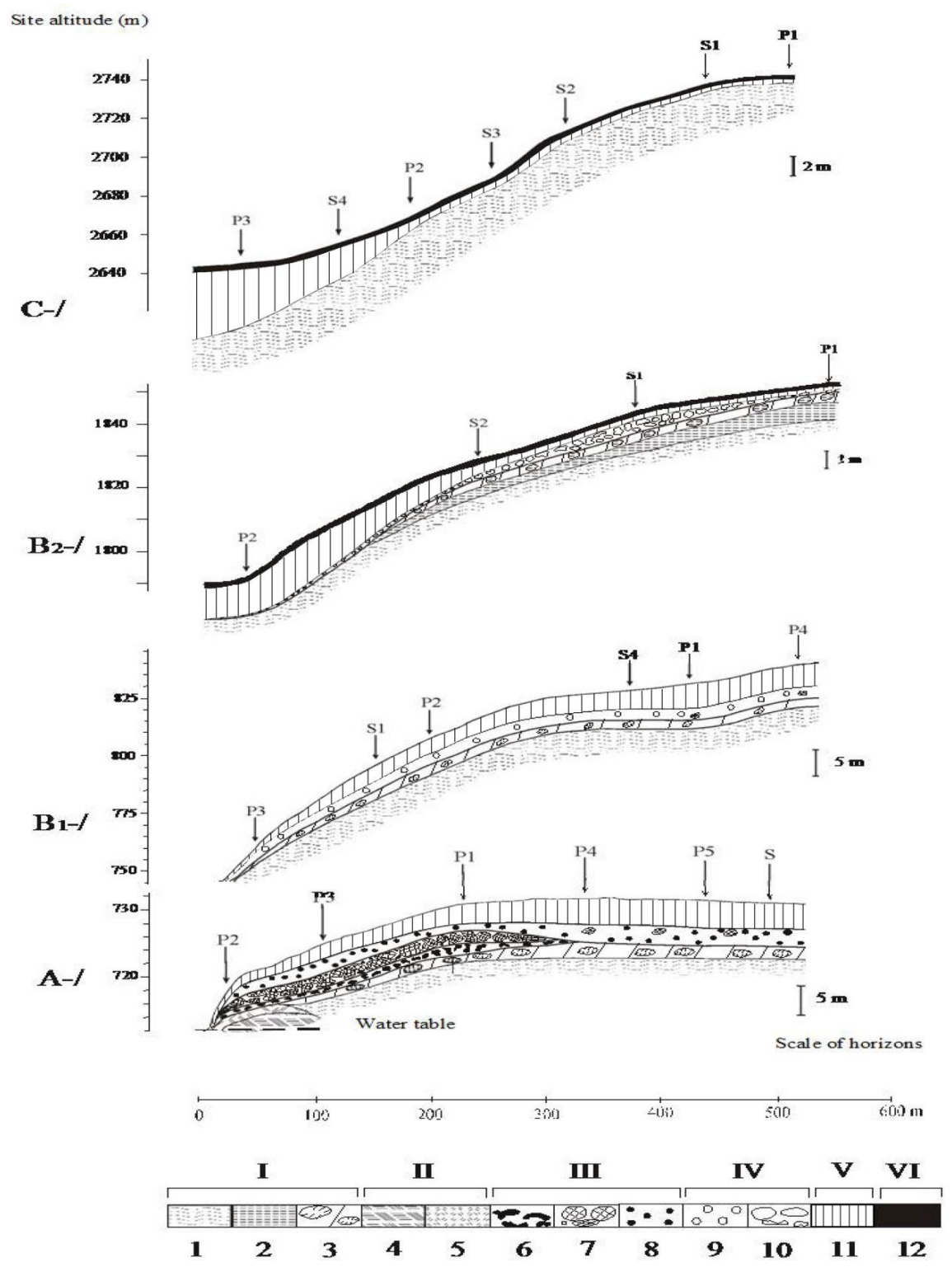

Fig. (2). Main pedological units and their spatial distribution. . (A) In the tropical plateau landscapes - "Mayos site" in the South Cameroon Plateau; (B) In the high plateau landscapes (800-2000 m altitude): $\mathbf{B}_{1}$ ) "Mbalam site" in the South Cameroon Plateau; $\mathbf{B}_{2}$ ) "Meloung site" in the Western Highlands of Cameroon; (C) In the mountainous massif landscapes (altitude above $2000 \mathrm{~m}$ ) - "Meleta site" in the Western Highlands of Cameroon; I: Weathering horizons: 1) Greyish, yellowish isalteritic horizon with preserved parent rock structure (HIG); 2) Mottled isalteritic horizon with preserved parent rock structure (HIB); 3) Alloteritic red horizon with isalteritic relics (HAR); II: Foot of slope ferruginous accumulations: 4) Mottled horizon, massif, humid and tender at its base, with loamy texture (HBM); 5) Spotted horizon that hardens into carapace at its summit (HTI); III: Ferruginous glaebular horizons: 6) Ferruginous pebbly horizon with ferruginous dark brown pebbles embedded in a red clayey matrix (HCF); 7) Blocky iron duricrust horizon (HBF); 8) Spotted and compact ferruginous nodular horizon, with dark brown ferruginous nodules embedded in a red clayey matrix (HNF); IV: Gibbsitic glaebular horizons: 9) Gibbsitic nodular horizon with light brown gibbsitic nodules embedded in a red clayey matrix (HNG); 10) Gibbsitic glaebular horizon with whitish gibbsitic plates embedded in a red clayey matrix (HGG); V: Loose clayey horizons: 11) Set of loose, red to yellowish red clayey horizons (HAM); VI: Humiferous horizons with andosolic properties: 12) Humiferous horizon with andosolic properties, loamy, thick and dark (HHA); P: Pit ; S: auger borehole.

mottled unit (Fig. 2A). Their respective thicknesses exceed $1 \mathrm{~m}$. They are both massive and loamy with juxtaposition of yellowish to whitish grey (10YR8/1), red (10YR4/6) and yellowish brown (10YR6/8) or reddish brown (7.5YR5/8) domains with an inherited schistose structure. Microscopically, like in the isalteritic domains, the yellowish grey to whitish domains are very rich in muscovite, while the red domains instead show numerous kaolinite crystals buried in a weakly birefringent reddish brown plasma (Fig. 3). Towards the surface, in the spotted horizon, the isalteritic domains are not preserved, while the other domains show lighter or darker colours and reduced sizes, millimetre to centimetre, with a simultaneous hardening into a carapace. 


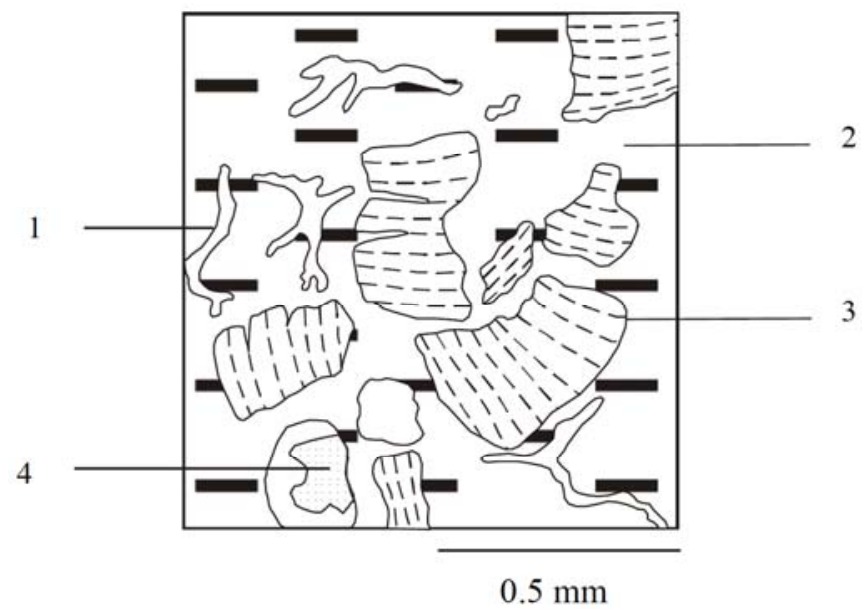

Fig. (3). Microscopic organization of brownish red domains of the mottled or spotted horizons (plateau soils in "Mayos site").

1: Fissure void;

2: Poorly birefringent brownish red plasma;

3: Wrinkled kaolinite;

4: Quartz within a dissolution void.

The hardened ferruginous and iron blocky duricrust horizons are observed only on the slopes where their respective thicknesses attain 1.5 and $2 \mathrm{~m}$, respectively. They gradually disappear by pinching out upslope at the extreme slope of the interfluve (Fig. 2A).

The hardened ferruginous horizon is constituted by duricrust blocks moulded in a dark red (10YR3/6), loose and fragile clayey matrix. The duricrust blocks, 60 to $70 \%$ of the horizon, have variable shapes; their groundmass presents abundant (70 $\%$ of GM), dense, black to isotic plasma, with a skeleton composed of muscovite and quartz; voids (10\% of GM) result mainly from quartz dissolution.

The iron blocky duricrust horizon contains very abundant (more than $85 \%$ of the horizon) iron duricrust blocks, metre and greater, separated by a lightly abundant red (10R4/6), loose and clayey matrix. The duricrust blocks are very hard and show very variable facies like massive, alveolar, isalteritic facies. They are microscopically identical to the hardened ferruginous horizon.

The ferruginous nodular horizon, spotted and compact, is 0.9 to $2 \mathrm{~m}$ thick from the foot of the slope to the interfluve's summit (Fig. 2A). It is composed of ferruginous nodules (50 to $60 \%$ of the horizon), centimetre scale, dense and very hardened, moulded in a heterogeneous matrix. The matrix is globally red (10R4/6), but presents numerous yellow or orange patches whose diameters range from a few millimetres to a few centimetres.

The upper part of the soils is represented by a clayey unit of horizons, red (10R4/4 to 10R4/6) and loose, with a polyhedral or locally micro-aggregate structure. The unit is 1 to $4 \mathrm{~m}$ thick from the foot of the slope to the interfluve's summit (Fig. 2A). Microscopically, it appears as a red GM with abundant (about $70 \%$ of the GM) and very birefringent plasma, quartz skeleton (15\% of GM) and fissure and piling voids. The skeleton and the plasma together form a porphyroskelic assemblage.

Overall, the soils of tropical plateau landscapes are composed of loose materials and hardened ferruginous materials. The former are observed mainly at the base (weathering facies) and at the top (loose clayey horizons) of weathering profiles. The latter are predominant in the middle part of the profile; they include duricrust blocks, nodules and iron pebbles, but also mottled and spotted horizons hardened into carapaces at their surfaces and locally at the downslope ferruginous accumulation horizons.

3.1.1.2. Morphological Characteristics of the High Plateau Soils in the "Mbalam Site"

Four soil units were identified along the studied soil toposequence from bottom to top: a yellow to violet grey isalteritic horizon, a red alloteritic horizon, a gibbsitic nodular horizon and a red loose clayey unit (Fig. 2B $\mathbf{B}_{1}$.

The isalteritic horizon, more than $3 \mathrm{~m}$ thick and clayey silty in texture, is marked by a perfect conservation of the inherited structure of the underlying parent rock and the abundance of globular garnet crystals. Those crystals, 4 to $6 \mathrm{~mm}$ in diameter, are weathered to some extent. Under the microscope, in addition to the numerous fresh muscovite flakes, there is a network of ferruginous partitions either creating alveolar voids often filled with small gibbsite crystals or shading fresh garnet relics.

The overlying alloteritic horizon is 1.5 to $2 \mathrm{~m}$ thick (Fig. $\mathbf{2 B}_{1}$ ). It is composed of numerous isalteritic relics and small nodules, whose aspects are similar to the globular garnet of the isalteritic horizon. These skeletal materials are buried in a red (2.5Y4/6), clayey and loose matrix. The isalteritic relics are constituted by quartz and more or less altered garnet, and notably muscovite whose microscopic appearance reveals a predominant transformation into gibbsite (Fig. 4).

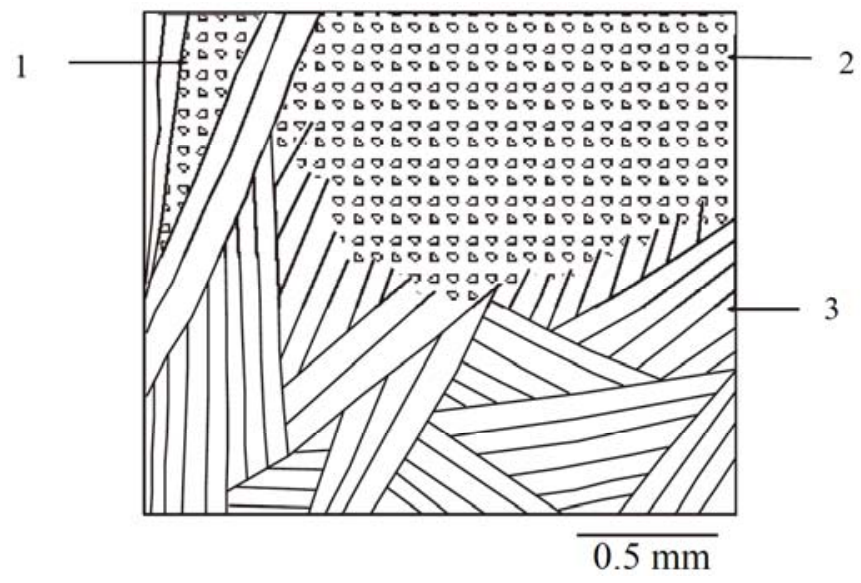

Fig. (4). Alteration of muscovite to gibbsite in the alloteritic horizon (high plateau soils in "Mbalam site").

1: Gibbsite crystallization between muscovite sheets;

2: Microcrystals of gibbsite;

3: Entangled lamellar crystals of muscovite.

The nodular horizon ( $1.5 \mathrm{~m}$ thick) is composed of light brown and hardened millimetre scale nodules, marked microscopically by an almost entirely gibbsitic crystic plasma. The gibbsitic nodules represent 40 to $50 \%$ of the horizon and buried in a red (10Y4/6), loose and clayey matrix containing numerous mica flakes.

The set of red and loose clayey horizons presents the same characteristics as those of the "Mayos site". There is, however, a clear persistence of muscovite flakes at the soil surface. The thickness of the set ranges between 0.4 and $5 \mathrm{~m}$ from the foot of the slope to the summit of the interfluve (Fig. $2 \mathbf{B}_{1}$ ). 
3.1.1.3. Morphological Characteristics of the High Plateau Soils in the "Meloung Site"

Six soil units were identified along the slopes of the studied interfluve; they include, from bottom to top: a whitish isalteritic horizon, a mottled isalteritic horizon, an alloteritic horizon, a gibbsitic nodular horizon, a loose clayey set, and a humiferous horizon with andosolic characteristics (Fig. 2B $\mathbf{B}_{2}$ ).

The isalteritic horizon is more than $2 \mathrm{~m}$ thick. It is whitish to whitish grey (10YR7/1), coherent and porous, with the conservation of the parent rock's saccharoidal aspect. Microscopically, the material shows a whitish GM (50\% of the GM), weakly birefringent and silasepic plasma, a skeletal fraction (40\% GM) composed of sanidine phenocrystals, opaque minerals and quartz grains. Voids are typically alveolar, of dissolution type. All the sanidine phenocrystals are partially or totally pseudomorphosed by gibbsite microcrystals.

The mottled isalteritic horizon, which disappears gradually at the foot of the slope through pinch out, has a maximum thickness of $1.8 \mathrm{~m}$ (Fig. $\mathbf{2 B}_{2}$ ). It is constituted by a juxtaposition of red (10YR4/6) isalteritic, brown (10YR5/8) and whitish grey (10YR7/1), loamy and porous domains. All those domains are microscopically characterized by the presence of abundant sanidine crystals, which are completely pseudomorphosed by gibbsite.

Like the previous horizon, the alloteritic horizon pinches out at the foot of the interfluve (Fig. $\mathbf{2 B}_{2}$ ). Its maximum thickness is $1.2 \mathrm{~m}$. With a silty clay texture, it is yellowish red (5YR5/8). Microscopically, it is marked by the presence of numerous light-coloured plates, composed either of sanidine phenocrystals completely pseudomorphosed by gibbsite, or gibbsitic crystallaria (Fig. 5).

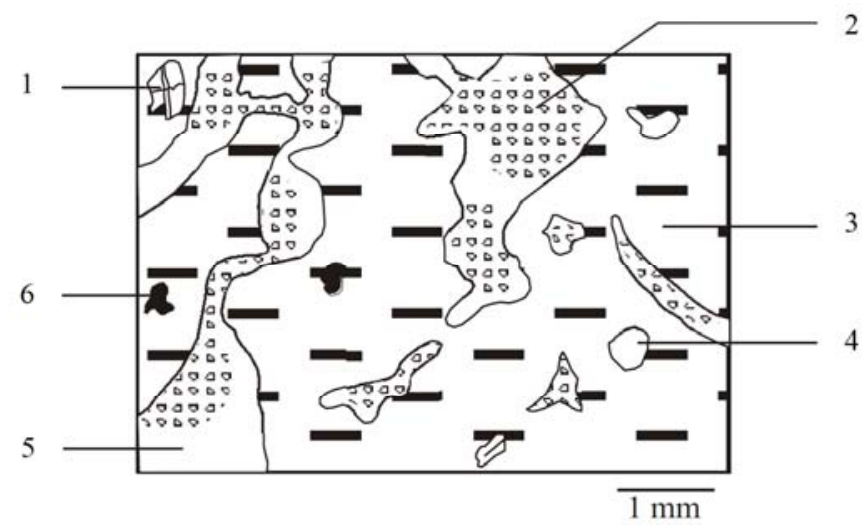

Fig. (5). Gibbsitic crystallarias in the voids of the yellowish red alloteritic horizon (high plateau soils in "Meloung site"). 1: Unweathered sanidine relict; 2: Gibbsitic crystallaria in voids; 3: Yellowish red to red plasma; 4: Alveolar void; 5: Fissure void; 6: Opaque mineral.

The glaebular horizon (layer rich in glaebules, which are coarse and hardened materials with irregular shapes with diameters greater than $2 \mathrm{~cm}$ ) is 40 to $50 \mathrm{~cm}$ thick at the foot and top of the interfluve, but $1.5 \mathrm{~m}$ on the hill slopes. It is composed of whitish gibbsitic, flaky, very hardened nodules representing 60 to $70 \%$ of the volume of the horizon, buried in a yellowish red (5YR5/6) clayey matrix. Microscopic observations of the glaebules reveal an entirely gibbsitic crystic plasma, with gibbsite microcrystals whose birefringence is attenuated by a reddish brown ferruginous patch covering it.

The red (5YR3/4 to 2.4YR4/6) loose horizon has a maximum thickness of $3.5 \mathrm{~m}$ at the foot of the interfluve (Fig. $\mathbf{2 B}_{2}$ ). It is clayey and finely polyhedral, with a high porosity.

Lastly, the humiferous andosolic horizon is 35 to $40 \mathrm{~cm}$ thick, black (2.5YR2,5/0), silty, lumpy and highly porous. Under the microscope, the horizon shows an abundance of $60 \% \mathrm{GM}$, very dark brown, isotic matrix, a very lightly abundant (less than $5 \%$ GM) skeleton, constituted by weathered sanidine crystals, opaque minerals, and abundant voids created by piling of aggregates. The skeleton and plasma together form an agglomeroplasmic assemblage.

Overall, the high plateau soils are distinct from the plateau soils by a remarkable presence of gibbsite in the profile, either in loose or hardened material, by the disappearance of hardened ferruginous materials at the benefit of hardened gibbsitic materials, and by thick andosolic humiferous horizon in the "Meloung site", situated at more than $1800 \mathrm{~m}$ altitude.

3.1.1.4. Morphological Characteristics of the Tropical Mountainous Massif Soils in the "Meleta Site"

Three pedological units were identified along the studied topo-sequence: an isalteritic horizon, a yellowish red loose clayey horizon and a humiferous andosolic horizon (Fig. 2C). Also frequent at the studied site were very hard whitish millimetre-scale crusts. These thin crusts, absent in the majority of the profiles, were not examined in the context of the present work.

The isalteritic horizon is yellowish brown (10YR6/4) to whitish grey (7.5YR7/0) and is more than $4 \mathrm{~m}$ thick (Fig. 2C). It shows similar morphological characteristics as the whitish to yellowish grey isalteritic horizon of the "Meloung site", notably with a remarkable gibbsite pseudomorphosis of sanidine crystals (Fig. 6).

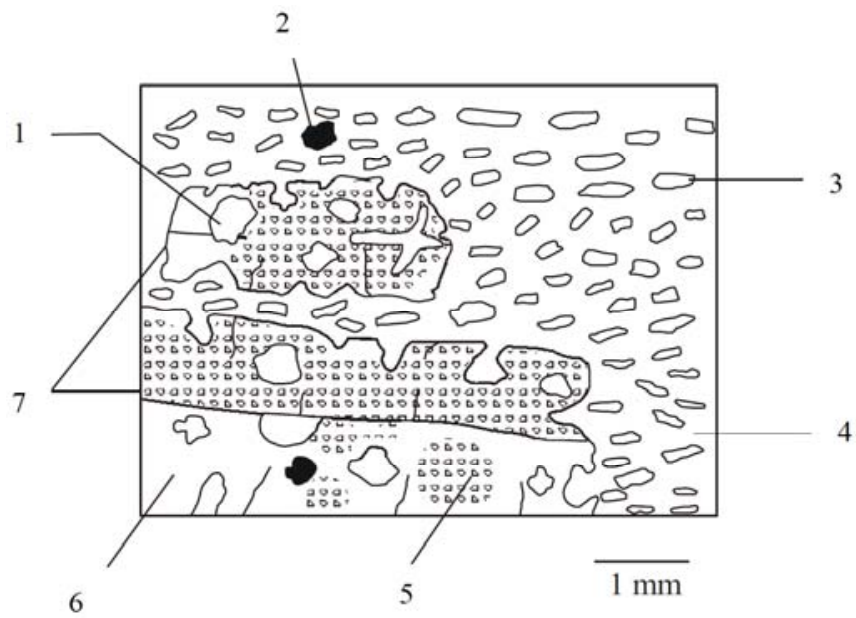

Fig. (6). Pseudomorphic weathering of sanidine in the isalteritic whitish grey horizon (mountainous massif soils "Meleta site"). 1: Dissolution void; 2: Opaque mineral; 3: More or less weathered sanidine microlites ; 4: Whitish grey groundmass; 5: Microcrystals of gibbsite; 6: Unaltered sanidine; 7: Sanidine phenocrystals partially or completely pseudomorphosed by microcrystalline gibbsite. 
The loose median clayey horizon shows a variable thickness of $50 \mathrm{~cm}$ at the summit of the interfluve and 4 to 5 $\mathrm{m}$ at the foot of the slope (Fig. 2C). Apart from a pale yellowish red (5YR4/4 to 5YR3/4) colour, it presents similar characteristics as that of the "Meloung site".

Likewise, the surface humiferous andosolic horizon presents similar morphological characteristics as that of the "Melong site", with the only difference being that it is thicker at the interfluve's summit ( 0.4 to $0.5 \mathrm{~m}$ ) (Fig. 2C).

\subsubsection{Mineralogy and Geochemistry}

\subsubsection{Mineralogy and Geochemistry of "Mayos Site" Soils in the South Cameroon Plateau}

The plateau soils are composed of two types of materials: ferruginous hardened materials and clayey loose ones (Fig. 2A). Mineralogically, the hardened materials are essentially hematite, goethite and kaolinite; quartz, gibbsite and muscovite are also present, although in minute quantities (Table 5). The nodules of the nodular spotted horizon are the most haematitic. Goethite predominates in the isalteritic duricrust and in the brown red to brown hardened domains of the spotted horizon. Kaolinite is also well represented (Table 5). The mean chemical composition reveals that iron is the most abundant element in all the hardened materials ranging between $30.27 \% \mathrm{Fe}_{2} \mathrm{O}_{3}$ in the pebbles and $68.26 \% \mathrm{Fe}_{2} \mathrm{O}_{3}$ in the isalteritic duricrust (Table 1). Apart from iron, two other components are also quite abundant between $8.64 \%$ and $32.00 \%$ for $\mathrm{SiO}_{2}$, and 7.65 and $21.97 .00 \%$ for $\mathrm{Al}_{2} \mathrm{O}_{3}$ (Table 1). The other elements are negligible seldom attaining 1.00 $\%$ Oxide, apart from potassium with a mean value $3.24 \%$ in the ferruginous pebbles. The plot of the three most abundant elements in the $\mathrm{SiO}_{2}-\mathrm{Al}_{2} \mathrm{O}_{3}-\mathrm{Fe}_{2} \mathrm{O}_{3}$ triangular diagram reveals that all the hardened materials are localised towards the $\mathrm{Fe}_{2} \mathrm{O}_{3}$ pole (Fig. 7). More so, all the points are located on a straight line perpendicular to the $\mathrm{SiO}_{2}-\mathrm{Al}_{2} \mathrm{O}_{3}$ axis (Fig. 7) confirming the significant occurrence of a silica-alumina mineral in this material identified by the X-ray diffraction as kaolinite (Table 5). The Si/Al ratio fluctuates from 1 to 1.3 and is consistent with the occurrence of this silicate mineral (Table 1).

The loose materials (weathering facies, loose clayey set and fine earth cement of the hardened ferruginous materials) are mainly composed of kaolinite (Table 5); this mineral is associated with quartz and small proportions of goethite, hematite, gibbsite and even anatase. Muscovite is also present, but mainly in the lower part of these profiles (Table 5). Geochemically, $\mathrm{Si}$ is the most abundant element with only a very limited range between 55.80 and $57.55 \% \mathrm{SiO}_{2}$ (Table 1). This element shows a slight and progressive increase from the base to the top of the profile (Fig. 8). Apart

Table 5. Semi-Quantitative Mineralogical Composition of the Plateau Soils ("Mayos Site" in the South Cameroon Plateau)

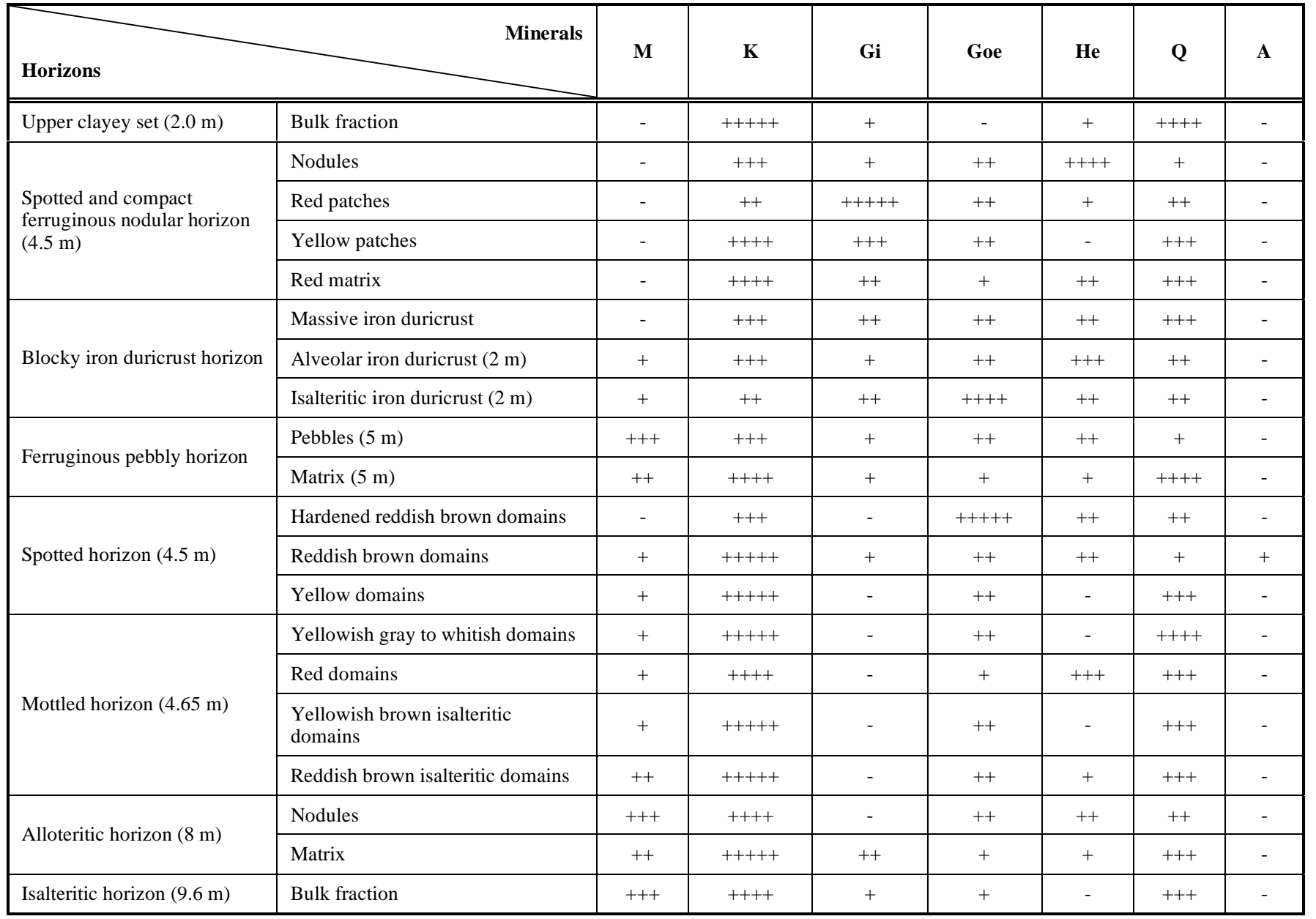

M: muscovite; K: kaolinite; Gi: gibbsite; Goe: goethite; He: hematite; Q: quartz; A: anatase; - : absent ; +: traces; ++: slightly represented; +++: represented; ++++: abundant; +++++: very abundant. 
from $\mathrm{Si}$, only $\mathrm{Al}$ and $\mathrm{Fe}$ are well represented in the profiles. $\mathrm{Al}$ has a contrary evolution trend to $\mathrm{Si}$ but not Fe (Fig. 8). At the foot of the slope, their contents range from 15.08 to $28.30 \%$ for $\mathrm{Al}_{2} \mathrm{O}_{3}$ and 5.64 and $8.07 \%$ for $\mathrm{Fe}_{2} \mathrm{O}_{3}$ (Table 1). At the foot of the slope, in the mottled and spotted horizons, $\mathrm{Fe}$ contents are higher (12.00 to $32.00 \% \mathrm{Fe}_{2} \mathrm{O}_{3}$ ) compared to Al (18.25 to $23.87 \% \mathrm{Al}_{2} \mathrm{O}_{3}$ ) and especially $\mathrm{Si}$ (34.10 to $49.09 \% \mathrm{SiO}_{2}$ ). Several elements show negligible proportions $(<2.00 \%)$, except in the isalteritic horizon, and notably at the surface of the profile with $4.45 \% \mathrm{~K}_{2} \mathrm{O}, 2.24 \% \mathrm{Na}_{2} \mathrm{O}$, $2.30 \% \mathrm{CaO}$ and $1.81 \% \mathrm{MgO}$ (Table 1). The $\mathrm{Si} / \mathrm{Al}$ ratio varies between 1.7 and 2.1, and reveals an excess of $\mathrm{Si}$ in agreement with the presence of quartz in the loose materials.

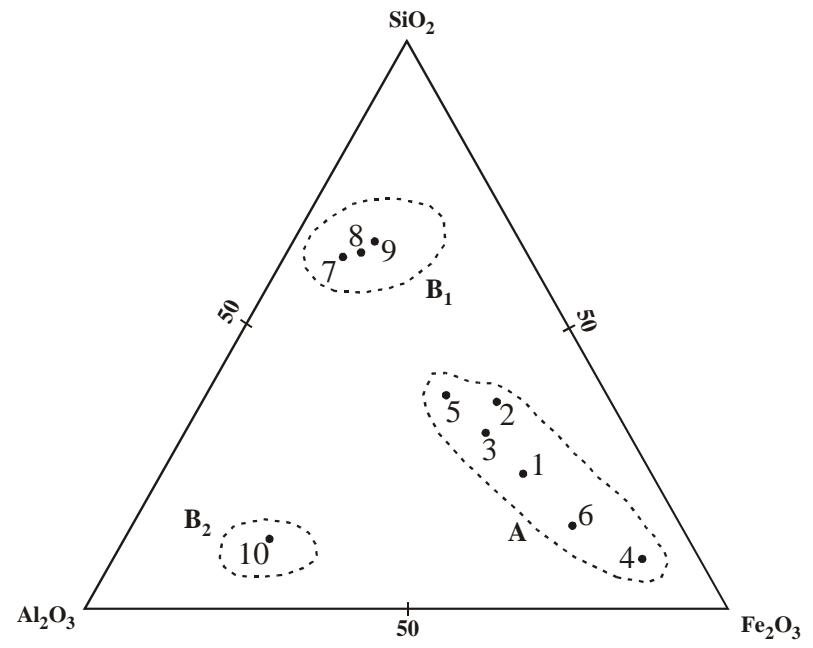

Fig. (7). $\mathrm{SiO}_{2}-\mathrm{Al}_{2} \mathrm{O}_{3}-\mathrm{Fe}_{2} \mathrm{O}_{3}$ triangular diagram of the different indurated soils material. (A) Indurated material of the plateau soils "Mayos site" (730 m altitude) in the South Cameroon Plateau: 1. Ferruginous nodules of the ferruginous nodular horizon (HNF); 2. Massive duricrust of the blocky iron duricrust horizon (HBF); 3. Alveolar duricrust of the blocky iron duricrust horizon (HBF); 4. Isalteritic duricrust of the blocky iron duricrust horizon (HBF); 5. Ferruginous pebbles of the ferruginous pebbly horizon (HCF); 6. Red brown indurated domains of the spotted horizon that hardens in carapace at its summit (HTI); (B) Indurated materials of the high plateau soils $\left(\mathbf{B}_{1}\right)$ "Mbalam site" (840 m altitude) in the South Cameroon Plateau: 7. Pseudomorphosed garnet of the greyish isalteritic horizon (HIG); 8. Gibbsitic nodules of the red alloteritic horizon (HAR); 9. Gibbsitic nodules of the gibbsitic nodular horizon (HNG); $\left(\mathrm{B}_{2}\right)$ "Meloung site" (1844 m altitude) in the Cameroon Western Highlands: 10. Gibbsitic plates of the gibbsitic glaebular horizon (HGG).

The soils of plateau landscapes are composed of hematite and goethite, which replace kaolinite in the hardened materials. The geochemical composition reveals the existence of iron, aluminium and silicon as dominant elements in the hardened materials, and the siliconaluminium couple takes over for iron in the loose material.

3.1.2.2. Mineralogy and Geochemistry of High Plateau Soils in the "Mbalam Site"

The soils of the "Mbalam site" present two main types of materials: hardened gibbsitic materials and loose clayey materials (Fig. 2B 1 ).

$\begin{array}{lllllllllllllll}0 & 5 & 10 & 15 & 20 & 25 & 30 & 35 & 40 & 45 & 50 & 55 & 60 & 65 & \text { Oxides (\%) }\end{array}$

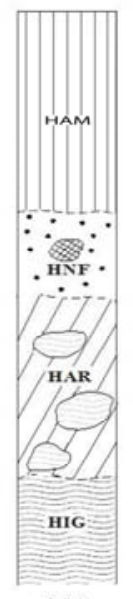

(A)

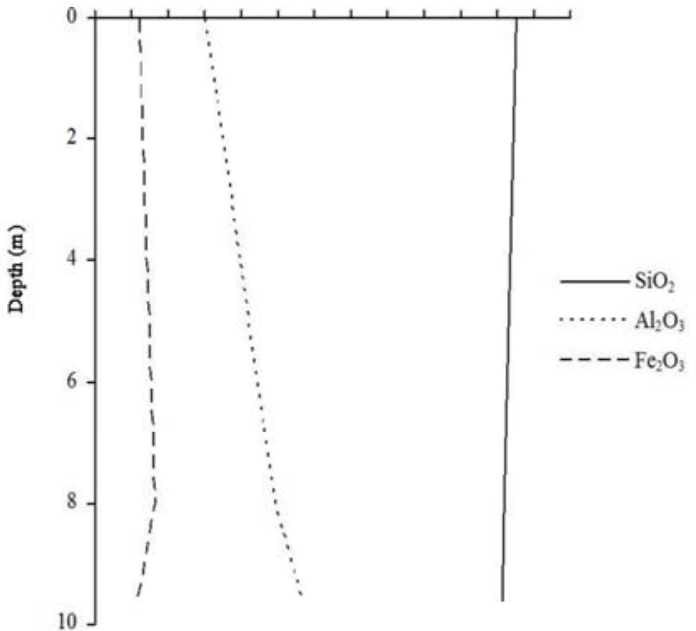

Fig. (8). Behaviour of $\mathrm{Fe}, \mathrm{Si}$ and $\mathrm{Al}$ in the loose materials of the plateau soils - "Mayos site" (A) in the South Cameroon Plateau (for key of A, see Fig. 2).

The hardened materials are composed mainly of gibbsite associated with goethite, hematite, quartz, muscovite and traces of kaolinite, anatase and ilmenite (Table 6). Major elements are well represented, with 42.98 to $47.23 \% \mathrm{SiO}_{2}$, 15.53 to $19.82 \% \mathrm{Al}_{2} \mathrm{O}_{3}, 5.65$ to $8.12 \% \mathrm{Fe}_{2} \mathrm{O}_{3}$, and 1.36 to $4.34 \%$ for $\mathrm{K}, \mathrm{Na}, \mathrm{Ca}$ and $\mathrm{Mg}$ (Table 2). The Si/Al molar ratio varies between 2 and 2.7 (Table 2), revealing excess $\mathrm{Si}$ in the materials. Also, the $\mathrm{SiO}_{2}-\mathrm{Al}_{2} \mathrm{O}_{3}-\mathrm{Fe}_{2} \mathrm{O}_{3}$ triangular diagram reveals that all of the points are located near the $\mathrm{SiO}_{2}-\mathrm{Al}_{2} \mathrm{O}_{3}$ axis, although with a displacement towards the $\mathrm{SiO}_{2}$ pole (Fig. 7). This is consistent with the abundance of $\mathrm{Al}$ in the material, although the composition is dominated by $\mathrm{Si}$. The abundance of $\mathrm{Si}$ as well the significant contents of alkaline and alkali earth components are in agreement with the abundance of primary minerals, quartz and muscovite.

In the loose material, gibbsite remains the predominant mineral, associated with kaolinite and traces of goethite, except in the isalteritic horizon. Quartz and muscovite are also well represented (Table 6). Geochemically, the characteristics of the loose materials are quite close to those of the hardened materials, with $\mathrm{Si}$ remaining most abundant (50.68 to $62.60 \% \mathrm{SiO}_{2}$ ) (Table 2). The $\mathrm{Si} / \mathrm{Al}$ molar ratio varies between 2.23 and 4 (Table 2) due to the strong persistence of primary minerals, quartz and muscovite. In detail, the very high proportion of silica in the isalteritic and nodular horizons decreases respectively in the alloteritic horizon, then in the loose clayey horizons; this behaviour induces a jig-saw shape $\mathrm{Si}$ evolution curve contrary to that of $\mathrm{Al}$, while that of $\mathrm{Fe}$ is constant (Fig. 9)

3.1.2.3. Mineralogy and Geochemistry of the "Meloung Site" Soils

The "Meloung site" soils in the West Cameroon Highlands, just like those of the "Mbalam site", are composed of two types of materials: the hardened gibbsitic material and the loose clayey material (Fig. $2 \mathbf{B}_{\mathbf{2}}$ ).

The hardened materials are almost entirely gibbsite (Table 7). Besides gibbsite, small contents of goethite and traces of kaolinite, hematite, quartz, anatase and magnetite 
Table 6. Semi-Quantitative Mineralogical Composition of the High Plateau Soils ("Mbalam Site" in the South Cameroon Plateau)

\begin{tabular}{|c|c|c|c|c|c|c|c|c|c|c|}
\hline \multicolumn{2}{|l|}{ Horizons } & $\mathbf{M}$ & $\mathbf{K}$ & Gi & Goe & $\mathbf{H e}$ & $\mathbf{Q}$ & $\mathbf{A}$ & Cal & Ilm \\
\hline Upper clayey set $(1.5 \mathrm{~m})$ & Bulk fraction & + & +++ & ++ & - & + & ++++ & - & - & - \\
\hline \multirow{2}{*}{$\begin{array}{l}\text { Gibbsitic nodular horizon (5.5 } \\
\text { m) }\end{array}$} & Nodules & + & - & ++++ & ++ & ++ & +++ & - & - & - \\
\hline & Matrix & ++ & ++ & ++ & - & + & ++++ & + & - & - \\
\hline \multirow{2}{*}{ Alloteritic horizon } & Nodules & + & + & +++ & ++ & + & +++ & + & - & - \\
\hline & Matrix & ++ & ++ & ++ & - & + & ++++ & + & - & - \\
\hline \multirow{2}{*}{ Isalteritic horizon ( $9 \mathrm{~m})$} & Slightly weathered garnet & ++ & + & +++ & ++ & + & ++ & + & - & + \\
\hline & Isaterite $(9 \mathrm{~m})$ & +++ & + & ++ & +++ & - & +++ & - & + & - \\
\hline
\end{tabular}

M: muscovite; K: kaolinite; Gi: gibbsite; Goe: goethite; He: hematite; Q: quartz; A: anatase; Cal: calcite; Ilm: ilmenite; -: absent; +: traces; ++: slightly represented; +++: represented; ++++: abundant; +++++: very abundant.

are present (Table 7). The mean chemical composition reveals that $\mathrm{Al}$ is the most abundant element $(46.80 \%$ $\left.\mathrm{Al}_{2} \mathrm{O}_{3}\right)$, followed by $\mathrm{Fe}\left(16.20 \% \mathrm{Fe}_{2} \mathrm{O}_{3}\right)$ and $\mathrm{Si}(7.53 \%$ $\left.\mathrm{SiO}_{2}\right)$. Apart from titanium $\left(1.25 \% \mathrm{TiO}_{2}\right)$, the other elements are practically absent, with less than $0.10 \%$ oxides (Table 3). The $\mathrm{SiO}_{2}-\mathrm{Al}_{2} \mathrm{O}_{3}-\mathrm{Fe}_{2} \mathrm{O}_{3}$ triangular diagram reveals a net displacement towards the $\mathrm{Al}_{2} \mathrm{O}_{3}$ pole (Fig. 7), meanwhile the very low $\mathrm{Si} / \mathrm{Al}$ ratio confirms the abundance of $\mathrm{Al}$, as well as a net Si deficit (Table 3).

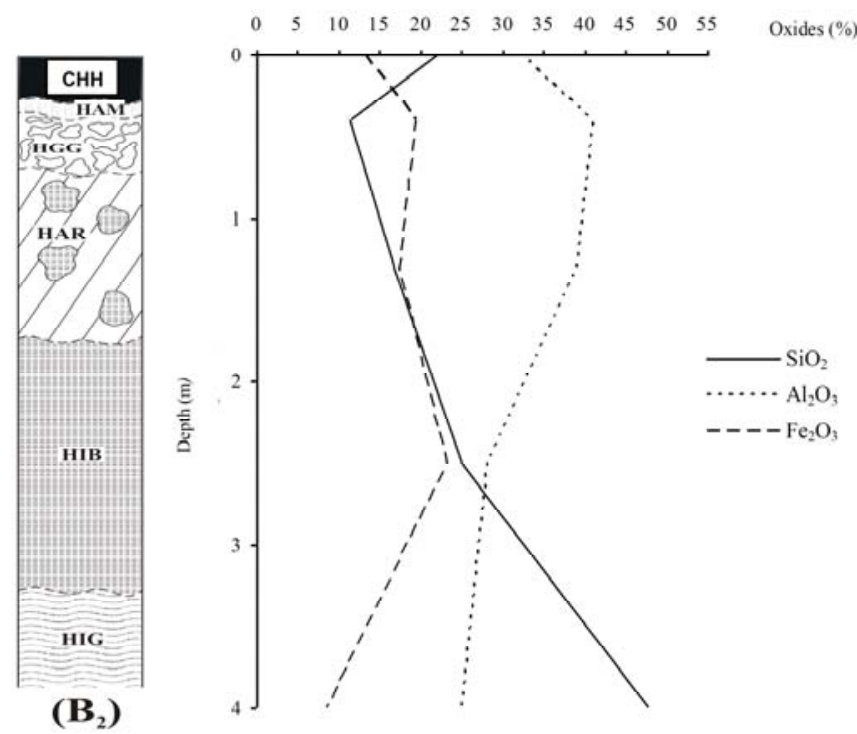

Fig. (9). Behaviour of $\mathrm{Fe}, \mathrm{Si}$ and $\mathrm{Al}$ in the loose materials of the high plateau soils - "Meloung site" $\left(\mathrm{B}_{2}\right)$ in the Cameroon Western Highlands (for key of $\mathrm{B}_{2}$, see Fig. 2).

The loose materials (weathering horizons, clayey set and humiferous andosolic horizon) are also mainly gibbsite (Table 7). At the base of the profiles, there is a remarkable persistence of sanidine and cristobalite, and especially the presence of halloysite in the humiferous andosolic horizons, where allophane also occurs (Table 7). Apart from the whitish and yellowish grey isalteritic horizon, $\mathrm{Al}$ is the most represented element (28.10 to $40.90 \% \mathrm{Al}_{2} \mathrm{O}_{3}$ ), followed by Fe (13.25 to $\left.23.20 \% \mathrm{Fe}_{2} \mathrm{O}_{3}\right)$ and $\mathrm{Si}$ (11.40 to $24.90 \% \mathrm{SiO}_{2}$ ), meanwhile alkaline and alkali earth components are almost completely absent (Table 3). At the base of profiles, the isalteritic horizon has an intermediate composition between the underlying trachyte and the overlying weathering mantle. Particularly, Si and alkaline elements are relatively abundant with mean values of $47.80 \% \mathrm{SiO}_{2}, 2.71 \% \mathrm{~K}_{2} \mathrm{O}$ and $2.80 \%$ $\mathrm{Na}_{2} \mathrm{O}$, while $\mathrm{Fe}$ and notably $\mathrm{Al}$ remain relatively modest (25.00\% $\mathrm{Al}_{2} \mathrm{O}_{3}$ and $8.40 \% \mathrm{Fe}_{2} \mathrm{O}_{3}$ ) (Table 3). $\mathrm{Al}$ and $\mathrm{Si}$ show contrary evolution trends from the base to the top of the profile, while Al increases continuously from the base to the surface where a slight decrease is observed. The evolution of iron is irregular with depth (Fig. 10). The Si/Al ratio is very low, ranging from 0.25 to 0.78 (Table 3 ), showing a net predominance of $\mathrm{Al}$ over $\mathrm{Si}$, except at the base of the profiles where it attains a value of 1.71 .

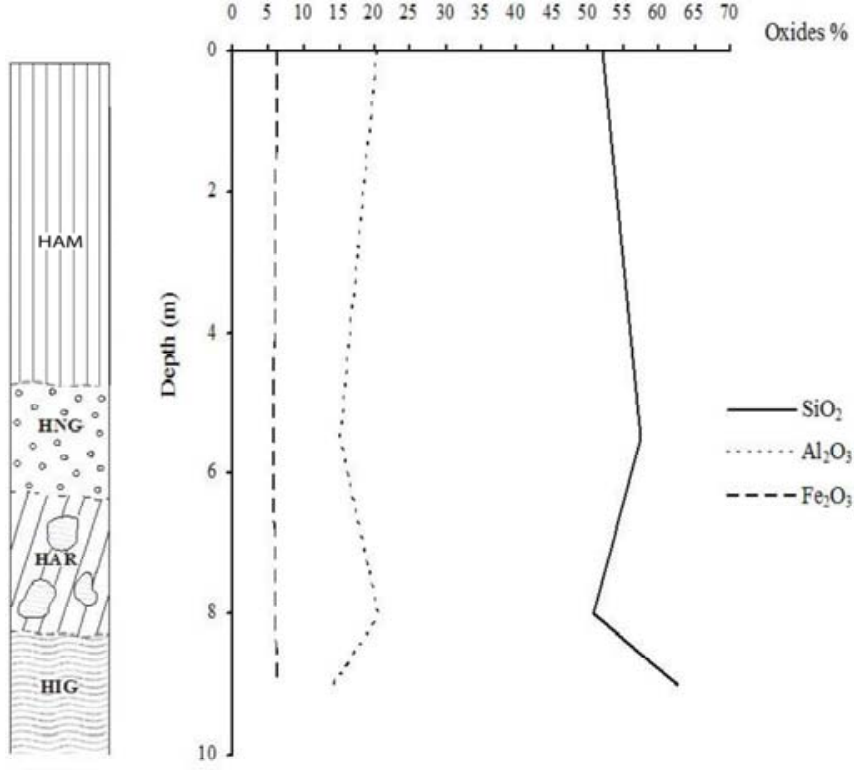

$\left(B_{1}\right)$

Fig. (10). Behaviour of $\mathrm{Fe}, \mathrm{Si}$ and $\mathrm{Al}$ in the loose materials of the high plateau soils - "Mbalam site" (B1) in the South Cameroon Plateau (for key of B1, see Fig. 2).

From a mineralogical and geochemical point of view, soils of the high plateau landscapes are principally aluminous, typically gibbsitic, and silicon poor. Important proportions of goethite and hematite are associated with the 
Table 7. Semi-Quantitative Mineralogical Composition of the High Plateau Soils ("Meloung Site" in the Cameroon Western Highlands)

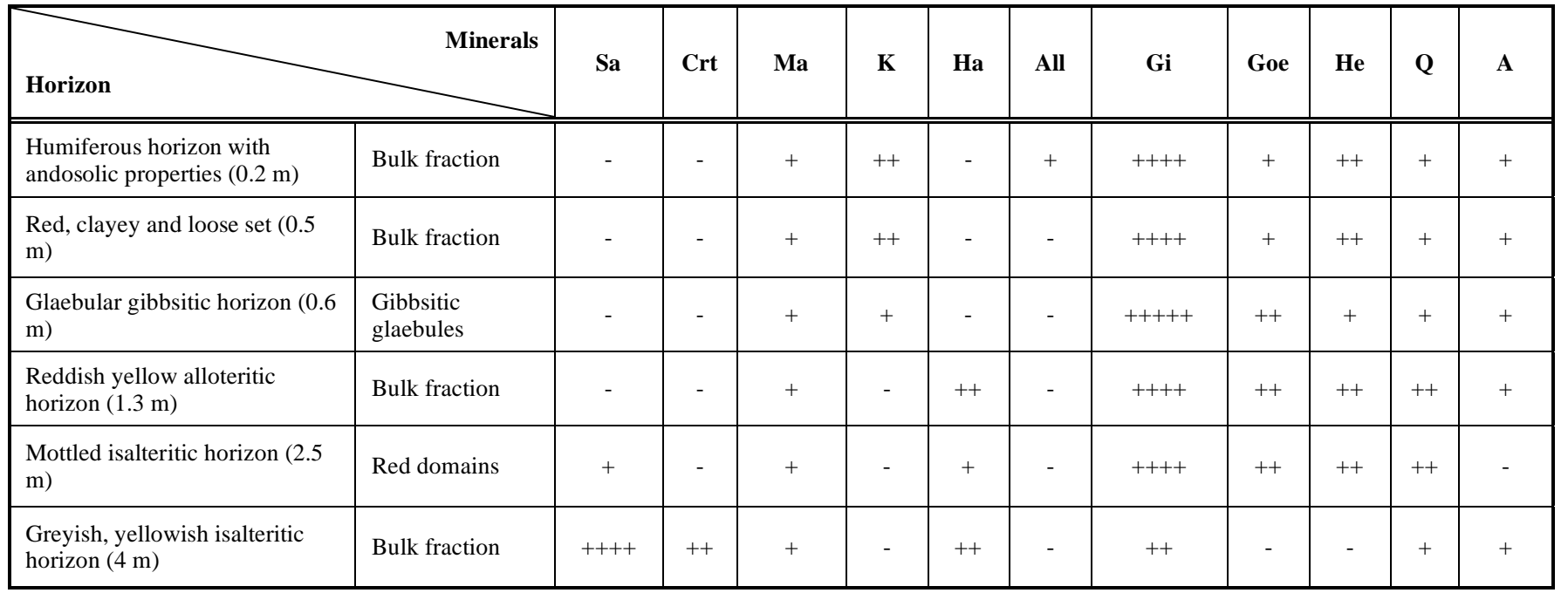

Sa: sanidine; Crt: cristobalite; Ma: magnetite; K: kaolinite; Ha: halloysite; All: allophane; Gi: gibbsite; Goe: goethite; He: hematite; Feh: ferryhidrite; Ilm: ilmenite; Q: quartz; A: Anatase; - : absent; +: traces; ++: slightly represented; +++: represented; ++++: abundant; +++++: very abundant.

gibbsite, both in the hardened materials and in the loose material. It is observed that the higher the altitude, like in "Meloung site" (1844 m altitude), the stronger the expression of aluminium in almost the entire profile, except in the humiferous horizon with a small quantity of silicon combined to aluminium to form allophane.

3.1.2.4. Mineralogy and Geochemistry of the Tropical Mountainous Massif Soils in the "Meleta Site"

High mountainous massif soils are composed mainly of loose materials. The mineralogical study reveals a strong expression of gibbsite, a remarkable occurrence of amorphous minerals (allophane and ferrihydrite) and the complete absence of kaolinite, which has been replaced by halloysite (Table 8). In addition, there are traces of quartz, rutile, goethite, hematite and magnetite, or sanidine and ilmenite especially at the base of the profile. Halloysite and gibbsite are more strongly expressed in the lower half of the profile, contrary to allophane, which is more abundant in the upper half.

From a geochemical point of view, $\mathrm{Al}$ and $\mathrm{Si}$ are the two most abundant elements 20.30 to $41.10 \%$ of $\mathrm{Al}_{2} \mathrm{O}_{3}$ and
21.50 to $23.80 \%$ of $\mathrm{SiO}_{2}$, respectively (Table 4). Contrary to $\mathrm{Si}$ which is almost constant along the profile, Al decreases throughout, gradually at first, then sharply from the humiferous horizon with andosolic features where Si appears to be the most strongly represented element (Fig. 11). Fe is also very abundant, although less than $\mathrm{Al}$ and $\mathrm{Si}$; its contents range between 6.63 and $8.94 \% \mathrm{Fe}_{2} \mathrm{O}_{3}$ (Table 4), and varies very slightly from the base to the top of the profile (Fig. 11). Apart from $\mathrm{Ti}$ whose contents attain $1.08 \% \mathrm{TiO}_{2}$, all the other elements show negligible abundances. The Si/Al ratio, 0.5 in the lower half of the profiles, increases towards the top and attains a value of 1 at the humiferous andosolic horizon (Table 4); it reveals the predominance of $\mathrm{Al}$ over $\mathrm{Si}$ in the lower half of the profiles, a net reinstatement of $\mathrm{Al}-\mathrm{Si}$ equilibrium in the upper part of the profile.

Overall, the soils of mountainous massif landscapes are clearly distinct from those of the previously studied landscapes by their richness in paracrystalline to amorphous minerals, notably halloysite, allophane and ferrihydrite. Si and $\mathrm{Al}$ are the most represented elements in this landscape and they are combined only in paracrystalline or amorphous

Table 8. Semi-Quantitative Mineralogical Composition of the Mountainous Massif Soils ("Meleta Site" in the Cameroon Western Highlands)

\begin{tabular}{|c|c|c|c|c|c|c|c|c|c|c|c|c|}
\hline Horizons & Minerals & Sa & Ma & Ha & All & Gi & Goe & He & Feh & Ru & Ilm & $\mathbf{Q}$ \\
\hline $\begin{array}{l}\text { Humiferous horizon with } \\
\text { andosolic properties } \\
(0.2 \mathrm{~m})\end{array}$ & Bulk fraction & - & + & + & ++ & +++ & + & + & + & + & - & + \\
\hline $\begin{array}{l}\text { Yellowish red clayey set }(0.7 \\
\text { m) }\end{array}$ & Bulk fraction & - & + & + & ++ & ++++ & + & + & - & + & - & + \\
\hline Isalteritic horizon & $\begin{array}{l}\text { Whitish gray domains (2 } \\
\mathrm{m})\end{array}$ & + & + & ++ & + & ++++ & - & - & + & - & + & + \\
\hline
\end{tabular}

Sa: sanidine; Ma: magnetite; Ha: halloysite; All: allophane; Gi: gibbsite; Goe: goethite; He: hematite; Feh: ferrihydrite; Ru: rutile; Ilm: ilmenite; Q: quartz; - : absent ; +: traces; ++: slightly represented; +++: represented; ++++: abundant; +++++: very abundant. 
forms. Iron is the last well represented element, even though its contents are modest (less than $9 \% \mathrm{Fe}_{2} \mathrm{O}_{3}$ ). The mineral paragenesis is completed by goethite.
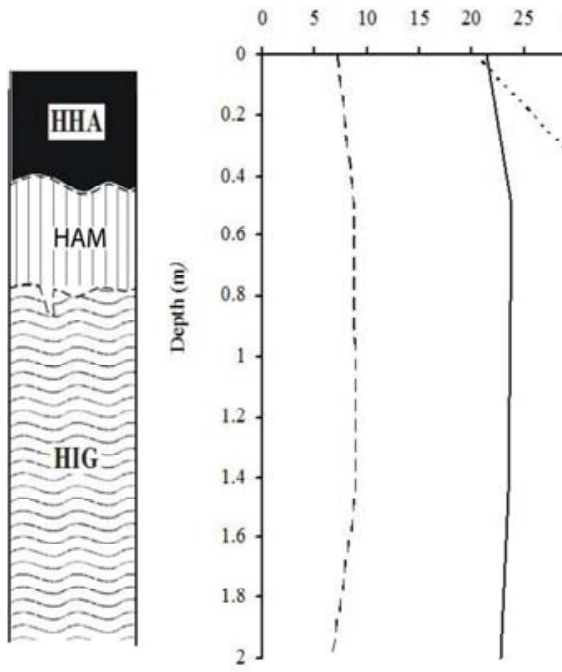

(C)

Fig. (11). Behaviour of $\mathrm{Fe}, \mathrm{Si}$ and $\mathrm{Al}$ in the loose materials of the mountainous massif soils - "Méléta site" (C) in the Cameroon Western Highlands (for key of C, see Fig. 2).

\section{DISCUSSION}

\subsection{Major Petrological and Geochemical Features of Tropical Soils: General Characteristics and Specificities of the Different Ecosystems}

In general, six major types of pedological volumes are distinguished in the humid tropical zone of Cameroon. They include the weathering horizons, foot of slope iron accumulation horizons, iron glaebular horizons, gibbsitic glaebular horizons, loose clayey horizons and humiferous horizons with andosolic features (Fig. 2). The spatial organization and the number of these different pedological units vary from one ecosystem to another, and moreover, some of their morphological, mineralogical and geochemical characteristics also appear to be specific to each ecosystem. These results agree with those of other authors in other parts of the world $[5,6,7,12,14,15]$.

The general features, just like the ecological particularities of those pedological volumes, can be summarized and discussed as follows:

\subsubsection{The Weathering Facies}

Two main types of weathering horizons can be distinguished: the isalteritic horizons, where the structure of the parent rock is perfectly preserved, and the alloteritic horizon, which overlies the previous one and where the structures of the parent rock are only locally preserved.

The isalteritic horizons, located at the base of profiles, are observed in all the ecosystems. From a morphological point of view, apart from the perfect conservation of the structures inherited from the respective parent rocks, those horizons are very thick (several meters), overall greyish to yellowish and at times reddish or violet, globally silty, and the GM, in which there is pseudomorphic weathering of primary minerals, except quartz. This mode of weathering ensures the perfect preservation of the parent rock structure $[9,27]$. These morphological characteristics are currently reported in the isalteritic horizons of in the humid tropical zone $[1,7,8,28]$.

From a mineralogical and a geochemical point of view, the characteristics of the isalteritic horizons are clearly more specific to the different ecosystems. The mineral paragenesis is, in fact, dominated by kaolinite in the plateaus, gibbsite associated with important proportions of iron oxides (goethite, hematite) in the high plateaus, and gibbsite-silicaalumina amorphous or paracrystalline halloysite-allophane couple of minerals in the mountainous massif landscapes. Such paragenesis has already been documented in plateaus $[8,27,29-33]$, high plateaus $[9,10,34]$ and mountainous massifs $[12,29]$. These mineralogical particularities seem to reveal the existence of clear-cut geochemical behaviours from the base of profiles from one ecosystem to another. Moreover, the geochemical data seem to strongly agree with the mineralogy, with a predominance of silicon and aluminium in the plateaus, aluminium more or less associated with iron in the high plateaus, and once more the predominance of aluminium and silicon in the mountainous massifs. It is sometimes observed in the plateaus and high plateaus that the $\mathrm{Si} / \mathrm{Al}$ ratio is far greater than 1 in kaolinitic or gibbsitic environments (1.74 to 4$)$. It is clear that these high $\mathrm{Si} / \mathrm{Al}$ ratios are related to the presence of aluminosilicate primary minerals as quartz, muscovite and sanidine in the different isalteritic horizons $[27,28]$.

The alloteritic horizons, present only in the plateaus and the high plateaus, are either nonexistent or poorly differentiated in the mountainous massifs. The absence of this horizon is frequently reported in the temperate zone [36], whose environmental conditions are very close to those of the high mountainous massifs. This might be related to the poor development of the weathering horizon in this type of physical environment $[1,37]$.

The isalteritic horizons are loose, clayey to silty clayey, red and metre to plurimetre (1 to $3 \mathrm{~m}$ ). At higher altitude, as in "Meloung site" at $1800 \mathrm{~m}$, they are thinner $(<1.20 \mathrm{~m})$ and faintly coloured in yellowish red. More so, they are kaolinitic and enriched mainly in Si and Al in the plateaus, but principally gibbsitic and predominantly alumina-rich in the high plateaus. Such mineralogical and geochemical characteristics are currently observed in alloteritic horizons of plateau $[8,16,38,39]$ and high plateau $[10,34,40]$ ecosystems.

\subsubsection{The Downslope Iron Accumulation Horizons}

These iron-rich materials are exclusively observed in the tropical plateau landscapes, always located in the foot of the slope of interfluves. At their roots, where they are often limited by a shallow groundwater reserve, the materials are massif and soft, rich in $\mathrm{Si}$ (34.10 to $\left.47.50 \% \mathrm{SiO}_{2}\right), \mathrm{Al}(18.3$ to $23.80 \% \mathrm{Al}_{2} \mathrm{O}_{3}$ ) and $\mathrm{Fe}\left(17.40\right.$ to $31.60 \% \mathrm{Fe}_{2} \mathrm{O}_{3}$ ), mainly in the form of kaolinite and goethite. Towards the surface, they are hardened into carapaces and more enriched in iron (about $55.00 \% \mathrm{Fe}_{2} \mathrm{O}_{3}$ ) at the detriment of $\mathrm{Si}$ and $\mathrm{Al}$ (less than $15.00 \%$ of the respective oxides). The iron occurs as hematite and goethite. This type of horizon is currently reported at the foot of slopes of interfluves in the humid tropical zone [8, 41-44]. Here, the groundwater fluctuations 
within the clayey materials at the gentle sloping foot of the slope provokes constant redistribution of iron with hard crusting under the influence of water stress generated by these ground water fluctuations [44]. A fraction of the iron redistributed is derived from the dismantling of old iron duricrusts at the up slope of the interfluve [8, 44].

The downslope iron accumulation horizons appear, therefore, to be very specific. This is, firstly, because of their spatial location exclusively in the plateaus between 500 and $800 \mathrm{~m}$ altitude, and secondly, by their topographic position at the foot of the interfluves. They are, thus, the most characteristic pedological volumes of these tropical plateau ecosystems [41-44].

\subsubsection{The Iron Glaebular Horizons}

The iron glaebular horizons are observed only in the tropical plateau landscapes. Covering the entire upslope of the interfluve, they are constituted by duricrust blocks, nodules and ferruginous pebbles buried in a fine loose clayey matrix. Many authors documented these materials as a degradation facies from a continuous duricrust in the humid tropical zone [6, 41, 45-51].

\subsubsection{The Gibbsitic Glaebular Horizons}

The glaebular gibbsitic horizons are represented only in the high plateaus between 800 and $2000 \mathrm{~m}$ altitude. They are hardened materials which are present in all the studied soils as plates or nodules, buried in a loose clayey matrix. They are very rich in $\mathrm{Al}$ (more than $45 \mathrm{Al}_{2} \mathrm{O}_{3}$ ), poor in $\mathrm{Si}$ and the $\mathrm{Si} / \mathrm{Al}$ ratio can attain 0.1 . Similar geochemical characteristics are often reported in lateritic bauxite materials of the humid tropical zone [10, 48-50]. They reflect an intense weathering of allitic type material marked mainly by the presence of gibbsite [51].

\subsubsection{The Loose Clayey Horizons}

Apart from the isalteritic horizons, the loose clayey horizons are present in all the ecosystems of the humid tropical zone. Nevertheless, some of their morphological, mineralogical and geochemical characteristics vary from one ecosystem to another. Their thicknesses are more important upslope of the interfluves in the plateaus ( 3 to $5 \mathrm{~m}$ ), and decrease with increasing altitude at the benefit of the down of slope sections. The thickness of the loose horizons at the upper part of the profile increases with altitude as already documented in the temperate zone [37]. This trend could be attributed to increasing colluviation from the upper parts of the interfluve with increasing altitude, slope, vegetation scantiness and more abundant precipitation, notably in the mountainous massifs. Also, the colours of those horizons vary in the same direction from light colour in the plateaus and high plateaus to a more intense colour in the mountainous massif soils. This observation is in agreement with that of other authors in the tropical zone [12, 35, 52]. If the light colours are due to the presence of hematite or goethite respectively of tropical soils [1, 41, 53, 54], the darker colour of mountainous massif soils, despite their higher iron contents $\left(8.75 \% \quad \mathrm{Fe}_{2} \mathrm{O}_{3}\right.$ here against $6.01 \%$ $\mathrm{Fe}_{2} \mathrm{O}_{3}$ in the plateau), could reflect the presence of organic matter in the horizons enriched in paracrystalline to amorphous minerals. The affinity of these minerals with organic matter and the stability of the bonding between them are well understood $[55,56]$.

Mineralogically, those materials are mainly composed of kaolinite in the plateaus, gibbsite in the high plateaus and gibbsitic associated with halloysite and allophane in the mountainous massif ecosystems. This is portrayed geochemically by very low $\mathrm{Si} / \mathrm{Al}$ ratios $(0.2$ to 0.6$)$ in the mountainous massifs and in the high plateaus in agreement with the high gibbsite content. However, very high Si/Al ratios (3.4 to 2.3) are signalled in the plateaus or in the lower part of the high plateau interval and corroborated by the abundance of residual primary minerals such as quartz and muscovite.

\subsubsection{The Humiferous Horizons with Andosolic Features}

The humiferous andosolic horizons are located only in the mountainous massifs and towards the upper limit of the high plateau altitude interval. Systematically, they owe their name as "andosolic" materials from their morphological, mineralogical, geochemical, biochemical and physicochemical characteristics [57-60]. In fact, they are relatively thick (45 to $60 \mathrm{~cm}$ ), humiferous, porous, lumpy and loamy horizons, with a mineral paragenesis dominated by paracrystalline to amorphous minerals especially allophane associated with gibbsite. They are very light materials rich in organic matter (up to $20 \% \mathrm{OM}$ ) and the $\mathrm{Al}_{0 \mathrm{x}}+0.5 \mathrm{Fe}_{\mathrm{ox}}$ could exceed $5 \%$. All those characteristics, frequently reported $[12,14,15,34,35,52,58,59]$, are not only related to the presence of a volcanic parent rock, but also to the adiabatic effect [52]. Such conditions are, in effect, favourable to the rapid neoformation of cryptocrystalline to amorphous minerals $[35,37]$.

\subsection{Influence of Altitude on the Petrology and Geochemistry of Tropical Soils}

The number, distribution and some petrological and geochemical characteristics of tropical soils vary from one altitudinal range to the next. Thus, within the humid tropical domain, a number of ecological particularities can be highlighted that reflect the specific geochemical functioning due to the differences in altitude and the local climate.

Thus, in the 500-800 m altitude ecosystems, which correspond to the tropical plateau, the soils show four types of horizons from base to surface of the profile. These types of horizons and soil organization are very characteristic of this ecosystem [8, 41, 42]. Globally, the tropical plateau soils are very thick and light in colour, marked mainly by the abundance of iron in the form of iron duricrust blocks, pebbles and carapaces or by the red, yellow or violet colour that they impose to the soils. In addition, there is a constant occurrence of silicon and aluminium, combined as kaolinite. These kaolinite minerals, associated with iron, generally show well defined forms [16, 38, 61, 62]. All these forms of iron constitute one of the most marked features of tropical plateau ecosystems and are commonly reported in the humid tropical zones [8, 38, 41, 45-47, 61]. They enabled one to refer to those landscapes as "iron landscapes" [3].

In the 800-2000 m altitude ecosystems (high plateau landscape), the soils also show four pedological units as in the previous ecosystem. There is, however, the absence of the downslope iron accumulation horizon, the replacement of 
the iron glaebular horizons in the median part of the soils by the gibbsitic glaebular horizons, and the appearance of the humiferous andosolic horizons. Also, weathering facies and loose clayey horizons, present both in the tropical and high plateau ecosystems, show different mineralogical and geochemical compositions. They are non- to slightly kaolinitic and very gibbsitic with a Si/Al ratio that attains a value of 0.25 (Table 7). Globally, the soils of the high plateaus differ from tropical plateau soils by a weaker expression of iron at the expense of aluminium, a very marked discretion of silicon, and an important and generalized crystallization of $\mathrm{Al}$ as gibbsite both in the hardened materials and in the loose ones. The predominance of alumina materials, poor in silica, in this altitudinal range of intertropical zones is broadly accepted [10, 34], and depicts the allitic nature of pedogenesis in this ecosystem [51]. Above $1800 \mathrm{~m}$ altitude, the appearance of amorphous minerals, mainly silica-alumina, in the surficial humiferous horizons is evidence of pedoclimatic conditions that favour the maintenance of silica at these temperatures [63], about 10 to $12^{\circ} \mathrm{C}$.

In the mountainous massifs, the soils are constituted only by three types of pedological units from the base to the surface. These soils are marked by the complete absence of hardened materials, a dark colour due to strong impregnation by organic matter, a mineral paragenesis of paracrystalline to amorphous especially allophane, associated with gibbsite. Here, $\mathrm{Al}$ and $\mathrm{Si}$ are the most abundant elements, meanwhile alkaline and alkali earth components are completely absent. This agrees with a dominant pedogenetic process that favours the formation of silica-alumina compounds as well as the neoformation and preservation of amorphous minerals $[14,35]$. This reveals a high intensity of weathering as already documented in the highest altitudinal ecosystems of the humid tropical zone $[12,51,32]$.

Overall, in the humid intertropical zone, there is net soil differentiation in relation to the variation of altitude, as follows: (1) in plateaus (500-800 m altitude), soils are controlled by iron geochemistry, in the presence of aluminium and silicon crystallized as kaolinite; (2) in high plateaus (800-2000 m altitude), soils are conditioned by aluminium geochemistry crystallized as gibbsite, $\mathrm{Si}$ is practically absent but iron may be significantly represented as goethite and hematite; (3) finally, in mountainous massifs (>2000 m altitude), soils are controlled by silicon and aluminium geochemistry, combined as amorphous minerals. There is the co-existence of amorphous and crystallized forms with a notable influence of organic matter.

From one ecosystem to the next, the most variable parameter is climate generated by altitudinal increment influenced by the adiabatic gradient. It defines a real soil climosequence in the humid tropical ecosystem, from plateaus towards tropical mountainous massifs in agreement with Duchaufour [37, 65] who reported a progressive transition from brown soils to podzols with increasing altitude in the temperate zone. The geochemical sequence of such a landscape permits a better understanding of the presence of andosols at the summits of tropical mountains $[11,15,35,57,58]$, as well as the location of bauxitic plateaus with respect to iron plateaus, notably in West Africa where both co-exist, the former always at the immediate lower altitude $[8,64]$.

It should, however, be noted that the altitudinal division of the tropical landscapes cited above is mostly respected only inside the continents, which are out of the direct influence of humid monsoon winds that rise from the oceans. The coastal areas influenced by winds show a local climate that is generally more humid than in the middle of continents, imposing a specific geochemical trend. Thus, bauxitic duricrusts, characteristic of high plateaus, appear at $500 \mathrm{~m}$ altitude in Ivory Coast [64], but always in the highest landscape positions in the absence of mountainous massifs or where andosols, characteristic of mountain massifs, are observed at less than $800 \mathrm{~m}$ altitude in the New Hebrides [14].

The natural evolution trend of a soil climosequence can be modified either by direct or indirect action of man [37]. Man intervenes directly by clearing, overgrazing and cropping which promote soil erosion [17]. The indirect action of man involves the progressive removal of primary (climax) vegetation and replacing it with secondary vegetation thereby modifying the type of humus $[17,65]$. The sequence might be slightly modified by some intrazonal factors like local climatic fluctuations caused by slope exposure and nature of the parent rock [65]. The nature of the parent material applies particularly to limestone outcrops where the soil levels are less pronounced compared to soil stages formed on silicate rocks [17].

\section{CONCLUSION}

The humid tropical zone is subdivided into three major altitudinal zones: the plateaus (500-800 m altitude), the high plateaus (800-2000 m altitude) and the mountainous massifs (>2000 m altitude). Due to the adiabatic cooling, each of these ecosystems is under the influence of a local humid climate, increasing with altitude, which has a direct bearing on the geochemical functioning and evolution of the soils, and permits the definition of a soil climosequence inside the intertropical domain. The present study revealed that in the tropical plateaus, the soils, thick and coloured, are marked by the presence of ferruginous, glaebular, duricrusted or carapaced horizons in the middle part of the profile and at the foot of the slope of the interfluves. These horizons, which often attain 4 to $5 \mathrm{~m}$ on the slopes, are mainly constituted by goethite and hematite, associated with kaolinite. This is geochemically portrayed by the predominance of the three elements $\mathrm{Fe}, \mathrm{Si}$ and $\mathrm{Al}$. In the two loose horizons (weathering horizons at the base and the loose clayey horizons at the surface), kaolinite is the predominant mineral, meanwhile iron oxides are sufficiently represented to impose a light colour to these horizons. In the high plateaus, the soils are also thick and coloured, but are distinct from the former by the complete absence of ferruginous horizons, replaced here by gibbsitic glaebular horizons, and by the predominance of gibbsite, occasionally associated with small proportions of iron oxides. Finally, in mountainous landscapes, the soils are thinner compared to those of the previous landscapes and completely lack hardened materials. They are overlain by a humiferous andosolic horizon, black, loamy to lumpy, rich in organic matter and allophane. Apart from the humiferous horizon, 
the absence of kaolinite and especially the importance of paracrystalline to amorphous minerals is the most characteristic feature of such soils. Geochemically, Si and Al are by far the most represented elements, despite $\mathrm{Si} / \mathrm{Al}$ values which are always below 1 due to the presence of free and crystallized $\mathrm{Al}$ in the form of gibbsite, besides the Si-Al combined forms, abundant and essentially amorphous in this ecosystem.

Overall, the soil climosequence studied inside the humid tropical zone reflects geochemical functioning processes that grade with altitude. Thus, in the tropical plateaus, soil evolution is conditioned by iron geochemistry; this landscape is relayed by high plateaus conditioned by aluminium geochemistry, and finally the mountain massifs where silicon combined with aluminium in the form of amorphous substances controls the geochemistry.

\section{CONFLICT OF INTEREST}

The authors confirm that this article content has no conflict of interest.

\section{ACKNOWLEDGEMENTS}

The authors duly thank the anonymous Reviewers for their helpful criticisms and suggestions that greatly improved the manuscript.

\section{REFERENCES}

[1] Tardy Y. Petrology of laterites and tropical soils. Paris: Masson 1993.

[2] Ségalen P. Soils and geomorphology of Cameroon. Cah Orstom (Sér Pédol) 1967; 5: 137-87.

[3] Eno Belinga SM. External dynamic geology of tropical countries of the earth. Iron landscapes. Yaoundé: University Library 1983.

[4] Nahon D. Iron duricrusting and limestone encrusting in Western Senegal and Mauritania. System of evolution: geochemistry, structures, relay and coexistence. PhD thesis. Marseille: University of St Jérôme 1976.

[5] Ambrosi JP. Petrology and geochemistry of a sequence of iron duricrust lateritic profiles in the Diouga region, Burkina Faso. PhD thesis. Poitiers: University of Poitiers 1994.

[6] Bocquier G, Muller JP, Boulangé B. Laterites: present knowledge and perspectives on their differentiation mechanisms. Paris: AFES 1984.

[7] Beauvais A. Petrological and geochemical study of duricrust lateritic alteration in the south east of Centrafrican Republic. J Géodyn 1989; 4; 2: 71-91.

[8] Bitom D, Volkoff B, Beauvais A, Seyler F, Ndjigui PD. Role of lateritic heritage and piezometric level in relief evolution. J Géosci 2004; 336: 1161-70.

[9] Hiéronymus B. Mineralogical study of bauxite deposits in West Cameroon. Cah Orstom (Sér Pédol) 1973; 1: 97-110.

[10] Nyobé JB. Geology of the Melan Bauxite deposit-Western Highlands-Republic of Cameroon. Ann Fac Sci 1993 (University of Yaoundé 1); 1: 188-97.

[11] Colmet-Daage F, Gautheyrou J, Gautheyrou M, Ségalen P. Study of allophanic soils derived from volcanic materials in the West Indies and Latin America, using differential dissolution technique. Cah Orstom (Sér Pédol) 1973; 2: 97-120.

[12] Rosello V, Brown soils of the Upper Reunion Islands. Mineralogical and microstructural characterisation of the andosolic materials. Experimental reconnaissance of their behaviour. $\mathrm{PhD}$ thesis. Paris: University of Paris VII 1984.

[13] Bravard S. Podzolization in the Brazilian Amazonia. Study of a ferrallitic soil-podzol sequence of the Manaus region. PhD thesis. Poitiers: University of Poitiers 1988.

[14] Quantin P. Soils of the New Hebrides (Venuatu) volcanic island chain. Study of the initial pedogenesis under tropical environment. Paris: Mém Orstom 1992.
[15] Tematio P, Kengni L, Bitom D, et al. Soils and their distribution in the Bambouto Volcanic mountain, West Cameroon Highlands, Central Africa. J Afr Earth Sci 2004; 39: 447-57.

[16] Bitom D. Organisation and evolution of a ferrallitic soil cover in the humid tropical zone of Cameroon. Genesis and transformation of the deep hardened iron horizons. PhD thesis. Poitiers: University of Poitiers 1988.

[17] Duchaufour PH. Pedology: Pedogenesis and classification. Paris: Masson 1977.

[18] Suchel JB. Rainfall distribution and rainfall regimes in Cameroon. Talence: CEGET;1972.

[19] Letouzey R. Notice of the phytogeographic map of Cameroon at 1:500.000. Toulouse: Inst de la Carte Internationale de la Végétation 1985.

[20] MUNSELL, Ed. The Munsell Soil Color Charts with genuine Munsell color chips. Revised edition. Florida: MUNSELL 2009.

[21] Hanrion Cl. Methods used for the confection of petrographic thin sections. Abidjan: ORSTOM 1976

[22] Brewer R, Ed. Fabric and mineral analysis on soils. London: Willey and Sons 1964.

[23] Brown GC, Brindley GW. In: Brindley GW, Brown GC, Eds. Xray diffraction procedures for clay mineral identification. London: Mineralogical Soc Monograph 5, pp.305-9, 1980.

[24] Holtzapfell T. Clay materials. Preparation, X-ray diffraction analysis and determination. Paris: Soc Géol Nord 1985.

[25] Van Der Marel HM, Beutelspacher H. Atlas of infra-red spectroscopy of clay minerals and their admixtures. Amsterdam: Elsevier Sci Pub Co 1976.

[26] FAO, Ed. World Base Reference for Soil Resources. Rome: FAOISRIC-IUSS 2006.

[27] Delvigne J. Pedogenesis under tropical environment, formation of secondary minerals under ferrallitic environment. PhD thesis. Paris: University of Paris VI, 1965.

[28] Lucas Y. Pedological Systems in Brazilian Amazon. Equilibria, disequilibria and transformations. PhD thesis. Poitiers: University of Poitiers 1989.

[29] Chatelin Y. Ferrallitic soils. Paris: Mém Orstom 1974

[30] Etame J, Bilong P, Bitom D, Robain H, Volkoff B, Eno Belinga SM. Yellow soil and red soil relationships in a soil sequence on gneiss in the forest zone of Cameroon. J Sci Tech Dév 1988; 1: 2937.

[31] Bilong P. Genesis and development of ferrallitic soils on alkaline potassic syenites in the forest zone of Central-South Cameroon. Comparison with ferrallitic soils developed on basic rocks. $\mathrm{PhD}$ thesis. Yaoundé: University of Yaoundé 1988.

[32] Bekoa E, Bilong P, Bitom D, Volkoff B, Eno Belinga SM Organisation of a yellow ferrallitic soil topo-sequence on low relief in the south Cameroon forest zone. Ann Fac Sci 1998 (University of Yaoundé 1); 34: 35-54.

[33] Nguetnkam JP, Bitom D, Yongue-Fouateu R, Bilong P, Eno Belinga SM, Volkoff B. Petrographic, mineralogical and geochemical study of a soil topo-sequence developed on granite in the South Cameroon Plateau. J Sci Tech Dév 2003; 1:35-43.

[34] Leumbe Leumbe O, Bitom D, Tematio P, Temgoua E, Lucas Y Study of andic ferrallitic soils on trachyte in the humid mountain zone (Bambouto mountains-West Cameroon). Etude Gestion sols 2005; 4: 313-26.

[35] Sieffermann G. Soils of some volcanic regions of Cameroonpedological and mineralogical variations from the equatorial to the tropical milieu. Paris: Mém Orstom 1973.

[36] Seyler F, Volkoff B. Spatialization of the pedological study of an elementary watershed in the dense forest using a TM image. Cah Orstom (Sér Pédol) 1993; 1; 1: 95-106.

[37] Duchaufour PH. Pedology: pedogenesis and classification. Paris: Masson 1983.

[38] Muller JP. Petrological analysis of a loose lateritic formation of Cameroon. Tracing of supergene differentiation by secondary mineral paragenesis. PhD thesis. Paris: University of Paris VII 1987.

[39] Bekoa E. Petrological and geochemical study of a soil cover on gneiss in the forest zone of Extreme South-Cameroon. $3^{\text {rd }}$ cycle thesis. Yaoundé: University of Yaoundé 11994.

[40] Eno Belinga SM. Weathering of basalt and bauxitization in the Adamawa (Cameroon). PhD thesis. Paris: University of Paris VI 1972. 
[41] Bilong P, Eno Belinga SM, Volkoff B. Evolution sequence of duricrust landscapes and ferrallitic soils in the tropical forest zones of Central Africa. Position of soils with spotted clayey horizons. J Acad Sci 1992; 314: 109-15.

[42] Seyler F. Research methodologies on the treatment of aerial Remote Sensing photographs, based on the prior analysis of superficial formations and their vegetation cover. PhD thesis. Paris; University of Paris VII 1986.

[43] Temgoua E, Bitom D, Bilong P, Ndjigui PD, Eno Belinga SM. In: Vicat JP, Bilong P, Eds. Downslope iron accumulations in the humid forest zone of Central Africa: morphology, facies and relationship with relief. Yaoundé: University Press 1999; pp. 22941.

[44] Temgoua E, Bitom D, Bilong P, Lucas Y, Pfeifer HR. Dismantling of duricrust landscapes in the Central african tropical zone, formation of present-day iron accumulations at downslope. J Géosci 2002; 334: 537-43.

[45] Beauvais A, Tardy Y. Degradation and dismantling of iron crusts under climatic changes in tropical humid environments. Chem Geol 1991; 107: 277-80.

[46] Bitom D, Volkoff B. Iron-removal alteration of a massive duricrust and formation of iron gravelly horizons in soils of humid central Africa. J Acad Sci 1993; 316:1447-54.

[47] Bitom D, Volkoff B, Abossolo-Angue M. Evolution and alteration in situ of a massive iron duricrust in Central Africa. J Afr Earth Sci 2003; 37: 89-101.

[48] Bardossy G. Lateritic bauxite deposits. In: ICSOBA, Ed. Proceedings of the $6^{\text {th }}$ international congress of the ICSOBA Academy held in Pocos de Caldas (Brazil); 1989 July 12-14: Zagreb: Yugoslavia 1989; pp.11-18.

[49] Kolbisek B. Geochemistry and petrography of lateritic bauxites in the Brazilian Amazon. Comparison with Africa, India and Australia. PhD thesis. Strasbourg: University of Strasbourg 1990

[50] Aleva GJJ. Essential differences between the bauxite deposits along the southern and northern edge of the Guiana Shield. Econ Geol 1993; 76:1142-52.

[51] Pédro G. Geochemical characterization attempt of the different zonal processes resulting from superficial weathering. J Acad Sci $1966 ; 262: 1828-31$

[52] Colmet-Daage F, Cucalon F, Delaune M, Gautheyrou J, Moreau B. Characteristics of Equatorial soils derived from volcanic ash.
Attempted characterization of tropical soils. Cah Orstom (Sér Pédol) $1967 ; 1: 3-38$

[53] Schwertmann U. Transformation of hematite to goethite in soils Nature 1971; 232: 624-5.

[54] Didier P. Paragenesis of iron oxides and hydroxides in bauxites and iron duricrusts. PhD thesis. Poitiers: University of Poitiers 1983.

[55] Colmet-Daage F, Gautheyrou J, Gautheyrou M, Kimpe C, Fusil G, Sieffermann G. Dispersion and fine fraction study of allophanic soils of the West Indies and Latin America. Cah Orstom (Sér Pédol) 1972; 13: 219-41

[56] Wada K, Kakuto Y, Muchena SM. Clay minerals and humus complexes in five Kenyan soils derived from volcanic ash Geoderma 1987; 39:307-21.

[57] Tejedor Salguero ML, Fernandez Caldas E, Quantin P. Climosequence on recent soils of the northern region of Tenerife (Canaries Islands). Ecology, morphology, and physico-chemical characteristics. Cah Orstom (Sér Pédol) 1978; 3 (pt 1): 251-64.

[58] Tejedor-Salguero ML, Quantin P, Fernandez Caldas P. Soil climatosequence study in the northern part of the Tenerife Island (Canaries Islands). Mineralogical characteristics, interpretation and classification. Cah Orstom (Sér Pédol) 1978; 1: 83-106

[59] FAO, Ed. World Base Reference for Soil Resources. Rome: FAOISRIC-IUSS 1993.

[60] Bisseck HI. Physical fundamentals of dynamic meteorology. Paris: Kartala 1995.

[61] Nahon D, Melfi A, Conte CN. Presence of an old system of lateritic iron duricrust transformation in South Amazon. In situ transformation to latosols under the actual equatorial forest. J Acad Sci 1989; 308: 87-109.

[62] Ngon Ngon JF. Morphological, mineralogical and geochemical study of lowland hydromorphic clays of the Yaoundé region (Cameroon). Application to the ceramics industry. Ann Fac Sci 2007 (University of Yaoundé I); 3: 1-14.

[63] De Coninck F. Major mechanisms of spodic horizon formation. Geoderma 1980; 24: 101-28

[64] Boulangé B. Bauxite deposits of Ivory Coast. Their facies, transformation, distribution and relief evolution. Paris: Mém Orstom 1984.

[65] Duchaufour PH. Abridged pedology. Paris: Masson 1995 